\title{
THE PROSECUTORIAL ORIGINS OF DEFENCE COUNSEL IN THE EIGHTEENTH CENTURY: THE APPEARANCE OF SOLICITORS
}

\author{
JOHN H. LANGBEIN*
}

\section{The Rule Against Defence Counsel}

ENGLISH criminal procedure was for centuries organised on the principle that a person accused of a serious crime should not be represented by counsel at trial. When the surviving sources first allow us to see something of how criminal trials in cases of treason and felony were conducted, we see the judges insistently enforcing the prohibition on defence counsel.' Into the eighteenth century, the leading treatise on criminal procedure, Serjeant William Hawkins' Pleas of the Crown, endorsed the rule against defence counsel. Since any defendant "of Common Understanding may as properly [defend himself] as if he were the best Lawyer", Hawkins explained in 1721, "it requires no manner of Skill to make a plain and honest Defence. ..."

The notion that criminal defence was a suitable do-it-yourself activity arose at a time when the whole of the criminal trial was expected to transpire as a lawyer-free contest of amateurs. The prosecution was also unrepresented. The victim of the crime usually served as the prosecutor, ${ }^{3}$ aided by other witnesses and sometimes by the lay constable. A lay magistrate, the justice of the peace, organised

\footnotetext{
- Chancellor Kent Professor of Law and Legal History, Yale University; Arthur Goodhart Professor in Legal Science, Cambridge University, 1997-98. I adhere in this article to conventions that I have followed in prior work using manuscript and antiquarian sources. Words abbreviated in the originals have been written out, missing punctuation supplied, and obvious misspellings corrected without disclosure. Spellings have been modernised, but not in the titles of books or pamphlets. I acknowledge with gratitude suggestions and references from John Beattie, James Oldham, and Michael Prichard, and the research assistance of Cary Berkeley Kaye.

1 For instances of criminal defendants complaining about being denied counsel, see, e.g., Jo/m Udall, 1 St. Tr. 1271, 1277 (Croydon Assizes 1590); John Lilburne, 4 St. Tr. 1269, 1294-96, 1317 (Com'n of oyer and terminer, London 1649); Christopher Love, 5 St. Tr. 43, 52-55, 61 (High Court 1651); Joln Twyn. 6 St. Tr. 513, 516-517 (Old Bailey 1663); Edward Coleman, 7 St. Tr. 1, 13-14 (King's Bench 1678); Stephen College, 8 St. Tr. 549, 570, 579 (Oxford Assizes 1681); Richard Noble et al., 15 St. Tr. 731, 747 (Surrey Assizes 1713).

2 William Hawkins, A Treatise of the Pleas of the Crown, vol, 2, p. 400 (London, 2 vols., 1716, 1721).

'Not, of course, in homicide cases, in which the task was sometimes taken up by the victim's kin, but in which the coroner system was the closest English approximation to Continental-style public prosecution by an investigating officer. (See also note 98 below.) For an indication of the extent of the coroner's activity in the later eighteenth century, see Wiltshire Coroners' Bills: 1752-1796 (Roy F. Hunnisett, ed.) (1981) (Wiltshire Record Soc., vol. 36).
} 
the prosecution witnesses for trial at a pretrial committal proceeding. ${ }^{4}$ Sir Thomas Smith's celebrated tract, which depicts a trial for robbery conducted in a county assize court in the middle of the sixteenth century, epitomises the criminal trial as an "altercation" between citizen accuser and citizen accused. ${ }^{5}$

The rule forbidding defence counsel also had a functional explanation. Denying representation obliged the accused to conduct his own defence. Because as a practical matter the defensive and testimonial functions were impossible to separate, the rule against defence counsel pressured the accused to respond on the merits to the charges against him, hence to become an informational resource for the trial court. Although not allowed to testify on oath until $1898,{ }^{6}$ the accused was permitted and expected to speak unsworn. ${ }^{7}$

Contemporaries were quite candid about the importance of keeping counsel from interfering with the court's mission of extracting information from the accused at trial. Keble J. explained to a murder defendant in 1651 why he rejected his request for trial counsel: "[W] hen should we have any man answer? [W] hen would men be executed for robbing, and stealing, and killing?"8 Hawkins, while claiming to regard the accused "as if he were the best Lawyer," also emphasised the importance to the court of obliging the accused to conduct his own defence. "[T]he very Speech, Gesture and Countenance, and Manner of Defence of those who are Guilty, when they speak for themselves, may often help to disclose the Truth, which probably would not so well be discovered from the artificial Defence of others speaking for them."

${ }^{4}$ I have recounted the origins and operation of the so-called Marian pretrial procedure in John $\mathbf{H}$. Langbein, Prosecuting Crime in the Renaissance (1974), pp. 5-125 [hereafter cited as Langbein, Prosecuting Crime]; John H. Langbein, "The Origins of Public Prosecution at Common Law" (1973) 17 American J. Legal History 313.

5 Thomas Smith, De Republica Anglorum, bk. 2, ch. 23, at p. 114 (Mary Dewar, ed., 1982) (1st ed. 1583, written c. 1565).

- Criminal Evidence Act, 61 \& 6 Vict., c. 36 (1898); see generally Joel N. Bodansky, "The Abolition of the Party-Witness Disqualification: An Historical Survey" (1981-82) 70 Kentucky L. J. 91. American jurisdictions followed the lead of the English in rendering civil parties competent, but acted in advance of the English in extending the reform to criminal defendants. The timing of the American legislation rendering criminal defendants competent has been linked to sectional strife about the testimonial disqualification of African-American slaves and freedmen. George Fisher, "The Jury's Rise as Lie Detector" (1997) 107 Yale L.J. 575, 662-697.

"For discussion of what I have called the "accused speaks" theory of the early modern English criminal trial, see John H. Langbein, "The Historical Origins of the Privilege Against SelfIncrimination at Common Law" (1994) 92 Michigan L. Rev. 1047, 1050-52 [hereafter cited as Langbein, "Privilege"]. The point is developed there that the "accused speaks" trial was inconsistent with any privilege against self-incrimination.

8 Christopher Love, 5 St. Tr. 43, 61 (High Court 1651).

${ }^{9}$ Hawkins, vol. 2, p. 400 . 


\section{A. Exclusions}

In theory, the courts recognised an exception to the rule against defence counsel for the case in which "some Point of Law arise[s], proper to be debated", ${ }^{10}$ but in practice this exception had little scope. The judges commonly denied requests for counsel, invoking the maxim that the court served as counsel for the accused. In Sir Edward Coke's formulation, "the Court ought to be ... of counsel for the prisoner, to see that nothing be urged against him contrary to law and right ...." The court-as-counsel rubric proved to be a shallow safeguard. As John Beattie observes, it meant "that the judges would protect defendants against illegal procedure, faulty indictments, and the like. It did not mean that judges would help the accused to formulate a defence or act as their advocates". ${ }^{2}$ Indeed, the idea of the court as counsel "perfectly expresses the view that the defendant should not have counsel in the sense that we would mean". ${ }^{13}$

Another exception to the rule against defence counsel in common law criminal procedure was that it did not apply to misdemeanour. We have no particularly satisfying account of why contemporaries thought it appropriate to deny defence counsel in cases of treason and felony while allowing it for misdemeanour. One factor that may have influenced the distinction was the peculiarity that the category of misdemeanour included some matters of a largely civil or regulatory character-for example, the liability of property owners and parishioners for the upkeep of the roads. ${ }^{14}$ When questions of property rights (the sphere in which lawyers were otherwise most prominent in civil practice) came into litigation, it would have been awkward to forbid counsel because an archaic form had characterised the issue as misdemeanour. ${ }^{15}$

10 Ibid.

11 Edward Coke, The Third Part of the Institutes of the Laws of England: Concerning High Treason, and Other Pleas of the Crown, and Criminal Causes (London 1644) p. 29 (posthumous publication, written 1620s-1630s). For discussion of the court-as-counsel rubric see Langbein, "Privilege", at pp. 1050-52; and John M. Beattie, "Scales of Justice: Defense Counsel and the English Criminal Trial in the Eighteenth and Nineteenth Centuries" (1991) 9 Law \& Hist. Rev. 221,223 [hereafter cited as Beattie, "Scales"].

12 Beattie, "Scales", p. 223.

13 lbid. (emphasis added).

14 Michael Dalton, The Countrey Justice, pp. 51-55 (London 1618).

15 As far back as the early decades of the seventeenth century, "it was apparently quite common for attorneys to act for individuals accused at quarter sessions of minor criminal offences." C.W. Brooks, Pettyfoggers and Vipers of the Commonwealth: The "Lower Branch" of the Legal Profession in Early Modern England (1986) p. 190 (reviewing several studies). Brooks also reports "demarcation disputes between barristers and attorneys over" the right of audience in such matters at quarter sessions, a struggle that the barristers ultimately won. Ibid. pp. 90-91. 


\section{B. Allowing Defence Counsel}

The rule forbidding defence counsel was abandoned piecemeal across the space of 140 years, from 1696 to 1836.

1. Full defence in cases of treason. The Treason Act of $1696^{16}$ first lifted the prohibition, but only for the handful of political players prosecuted for treason.

The Treason Act of 1696 was premised on the conclusion, formed in the aftermath of the political prosecutions under the later Stuarts, that the accused stood at a particular disadvantage in a treason case. The crown was invariably represented by counsel, whereas in cases of ordinary crime prosecuting counsel was hardly ever employed. Hawkins sought to reconcile the rule against defence counsel in felony with the exception permitting counsel under the Treason Act, on the ground that "Prosecutions of High Treason against the King's Person ... . are generally managed for the Crown with greater Skill and Zeal than ordinary Prosecutions. ..."17 Thus, the main rationale ${ }^{18}$ for the 1696 Act was evening up for the crown's perceived advantages in prosecuting treason. Furthermore, since treason cases were most infrequent by comparison with ordinary crime, a reform limited to treason cases did not risk impairing the routine administration of criminal justice.

2. Defence counsel to cross-examine in cases of felony. The turning point in overcoming the prohibition on defence counsel for cases of ordinary felony occurred in the eighteenth century, when the judges began to permit defence counsel to appear for the limited purpose of examining and cross-examining witnesses at trial. Stephen described this reversal in judicial practice as "[t]he most remarkable change" that took place in English criminal procedure from the time of its happening down to his own day. ${ }^{19}$

Working from the handful of felony cases reported in the State Trials, Stephen thought that the appearance of defence counsel to examine and cross-examine witnesses began in the second half of the

167 \& 8 Will. 3 , ch. 3 (1696). On the background to the legislation, see Alexander $H$. Shapiro, "Political Theory and the Growth of Defensive Safeguards in Criminal Procedure: The Origins of the Treason Trials Act of 1696" (1993) 11 Law \& Hist. Rev. 215; see also James R. Phifer, "Law, Politics, and Violence: The Treason Trials Act of 1696" (1980) 12 Albion 235; Samuel Rezneck, "The Statute of 1696: A Pioneer Measure in the Reform of Judicial Procedure in England" (1930) 2 J. Mod. Hist. 5.

17 Hawkins, vol. 2, p. 402.

18 Another factor that led Parliament to think that treason defendants stood in special need of defence counsel was mistrust of the bench. The Treason Act of 1696 was enacted in the aftermath of the treason trials of the later Stuarts, in which the bench displayed brazen partisanship for the crown. Until the Act of Settlement secured judicial independence, 12 \& 13 Will. 3 ch. $2, \S 3(1701)$, there was concern that the bench could not be trusted in treason trials. See John H. Langbein, "The Criminal Trial Before the Lawyers" (1978) 45 U. Chicago L. Rev. 263, 310 [hereafter cited as Langbein, "Lawyers"].

19 James Fitzjames Stephen, A History of the Criminal Law of England, vol. 1, p. 424 (1883) (3 vols.) [hereafter cited as Stephen, History]. 
eighteenth century. ${ }^{20}$ In an article published 20 years ago, I placed the development a generation earlier, in the mid-1730s. ${ }^{21}$ Using a set of pamphlet sources, the Old Bailey Sessions Papers, ${ }^{22}$ which supply synoptic accounts of the London felony trials held at the Old Bailey, I found that the earliest unambiguous case of defence counsel crossexamining prosecution witnesses dated from $1734 .{ }^{23}$ I found two further examples in 1735 , nine in $1736 .{ }^{24}$ Using similar sources for Surrey assizes, Beattie has documented the appearance of defence counsel in that court in the same period, including a case that occurred in $17322^{25}$

Legislation in 1836, the Prisoner's Counsel Act, expanded the role of defence counsel beyond the examination and cross-examination of witnesses, allowing so-called "full defence", that is, permitting counsel to address the jury, hence to offer observations about the evidence. ${ }^{26}$

\section{Ending the Altercation}

Having insisted for so long on the rule forbidding defence counsel in cases of felony, why did the judges abandon it in the mid-1730s? The scholarship has not had much to say about this question. In the article in which I reported the appearance of defence counsel in the Old Bailey in the mid-1730s, I observed that from the later 1710 s and into the 1720s the pamphlet sources evince a trickle of cases, about one a year, in which the appearance of prosecution counsel is reported. ${ }^{27}$ Such cases increased in frequency in the early $1730 \mathrm{~s}$. I noticed eight in the year $1734 .{ }^{28}$ Because the Old Bailey reports show greater resort to "prosecution counsel in the years just before the advent of defence counsel", I wondered whether "the resulting disparity may have influenced the judges to relax" the rule forbidding defence counsel, on analogy "to the developments precipitating the Treason Act of 1696 ". ${ }^{29}$ Just as the 1696 Act had allowed defendants to have counsel in order to even up for the prosecutorial advantages

\footnotetext{
${ }^{20}$ Stephen, History, vol. 1, p. 424.

2! Langbein, "Lawyers", pp. 311-312.

${ }^{22}$ The title wanders across the decades but is usually some variant of "The Proceedings on the King's Commissions of the Peace, Oyer and Terminer, and Gaol Delivery ... in the Old-Bailey, on [particular dates, also identified by London mayoral years]" [hereafter cited by month and year as OBSP].

${ }^{23} E-. J-.$, OBSP (Jul. 1734, \#39) 161, cited in Langbein, "Lawyers", p. 312 n. 161.

24 Langbein, "Lawyers", p. 312, n. 161. Years at the Old Bailey were reckoned from December of the previous calendar year, following the mayoral years of the City of London. Hence, the December 1735 sessions began the 1736 year.

${ }^{25}$ John M. Beattie, Crime and the Courts in England: 1660-1800 (1986), pp. 356-357 [hereafter cited as Beattie, Crime].

${ }^{26} 6$ \& 7 Will. 4 , ch. 114 (1836). On the background to the legislation, see David J.A. Cairns, Advocacy and the Making of the Adversurial Criminal Trial: 1800-1865 (1998), pp. 67-91.

${ }^{27}$ Langbein, "Lawyers", p. 311.

${ }^{28}$ Ibid. p. 312 \& n. 160 .

29 Ibid. p. 313 ; accord, Beattie, Crime, p. 359.
} 
of the crown in treason cases, so the judges of the 1730s might have been evening up for the greater presence of prosecution counsel in cases of ordinary felony in the mid-1730s.

One difficulty with this suggestion is that, to the extent that the Old Bailey reports can be trusted, ${ }^{30}$ prosecution counsel was still appearing in only a trickle of cases. Furthermore, the prosecution counsel do not appear to have had any particularly noteworthy effect on the conduct or the outcomes of the trials. Accordingly, it is a strain to see how these few appearances of counsel could have placed defendants in such peril that the judges would have felt constrained to abandon the longstanding rule against defence counsel that they had theretofore enforced so determinedly.

The present article reports on further research, directed to a wider set of sources, that has allowed me to see what was wrong with my initial suggestion. I was on the right track in suspecting that the judges were evening up for the advantages of the prosecution, especially prosecution lawyers, but I was wrong in pointing to the greater use of prosecution counsel at trial as the main event. The key developments in prosecutorial practice were occurring in the pretrial. As is so often the case in matters of criminal procedure, pretrial was shaping trial. A complex series of changes in the patterns of prosecution occurred across the early decades of the eighteenth century, particularly in London and its environs. These innovations in law enforcement entailed drastic departures from the sixteenthand seventeenth-century model of the trial as a contest of citizen equals.

The prosecutorial initiatives of the early eighteenth century that are canvassed in this article had two main lines of development: the use of solicitors to investigate and manage criminal prosecutions, and the reward system.

1. Solicitors. In the early decades of the eighteenth century, the work of investigating criminal cases, shaping criminal charges, and preparing evidence for trial became increasingly the province of solicitors. (This growing lawyerisation of the pretrial sometimes culminated in the use of prosecution counsel to present the case at trial, the phenomenon we can sometimes detect in the pamphlet sources that survive for the Old Bailey and for Surrey assizes.) I shall emphasise the work of solicitors for what $I$ call institutional prosecutors, such as the Mint, the Bank of England, the Treasury,

\footnotetext{
${ }^{30}$ On the reliability of the Old Bailey pamphlets, see John H. Langbein, "Shaping the EighteenthCentury Criminal Trial: A View from the Ryder Sources" (1983), 50 U. Chicago L. Rev. I, 21-26 [hereafter cited as Langbein, "Criminal Trial"], concluding that these sources do not fabricate but do compress and delete, hence cautioning that if the "report says something happened, it did; if the . . report does not say it happened, it still may have". Ibid. p. 25.
} 
and the Post Office. I also point to the growing use of solicitors by private prosecutors, and to the reinforcement for traditional private prosecution that resulted from the development of associations for the prosecution of felons. It will be seen that these widespread voluntary societies were intimately aligned with the solicitor's profession.

This article also points to the growing prominence of solicitors for the defence. The shady figures practising in London were known disparagingly as "Newgate solicitors". This epithet was also applied to some solicitors engaged in prosecution work. (Newgate was the prison that held persons awaiting trial at the Old Bailey.) By the 1730 s there was considerable alarm about the ability of Newgate solicitors to falsify or to tamper with evidence in ways that judge and jury might be unable to detect at trial, unless an adverse counsel was permitted to cross-examine the witnesses whom the solicitors had produced and prepared.

2. The reward system. In the same decades that solicitors were bringing legal professional reinforcement to a range of criminal prosecutions, the government launched a sustained effort to increase the levels of criminal prosecution by offering monetary rewards for the successful prosecution of offenders who committed certain of the more serious property crimes. The reward statutes called forth a mercenary proto-police, the thieftakers, who lived close to the London underworld on which they preyed.

The reward system proved to be fraught with incentives for false witnessing. Reward-seekers who received $£ 40$ per conviction had no intrinsic interest in convicting the guilty rather than the innocent. It will be seen that this central flaw of the reward system came sharply to public attention in the 1730 s, when the bench made its epochal decision to allow defence counsel.

This article is mainly devoted to the solicitors' increasing role in the prosecution of crime, a subject that has not been addressed in prior scholarship. The reward system was brought to prominence decades ago in Radzinowicz' History, ${ }^{31}$ and it has attracted further attention in recent years. Accordingly, in this article I am able to relate the reward system to my larger topic in a more summary fashion.

\footnotetext{
${ }^{31}$ Leon Radzinowicz, A History of English Criminal Law and Its Administration from 1750, vol. 2, pp. 57-137, 326-346 (4 vols. 1948-68) [hereafter cited as Radzinowicz, History] (treating statutory, nonstatutory, and private rewards).
} 


\section{Evening Up}

The theme of this article is that these two innovations in prosecutorial practice precipitated the judges' decision in the mid-1730s to allow the criminal defendant to have the assistance of counsel for the limited purpose of probing the prosecution evidence presented at trial. Experience with the new prosecutorial techniques caused the bench to conclude that too many of the criminal trials over which they presided were ceasing to resemble Sir Thomas Smith's altercation of unaided victim and accused. Especially in London, prosecution was becoming ever more the province of lawyers and of a questionable corps of reward-seeking thieftakers. These determined operators were employing means that increased the danger that the prosecution evidence coming before the courts could be unreliable. By allowing defence counsel to cross-examine prosecution witnesses, the judges attempted to correct for the imbalance that had opened between the unaided accused and a criminal prosecution that increasingly reflected the direction of lawyers and other "professionals". The bench was acknowledging that prosecution evidence needed probing of a sort that itinerant trial judges processing huge caseloads were not prepared to do. The rubric of court as counsel was relaxed in favour of counsel as counsel

\section{Solicitors in CRiminal Procedure: GLIMPSING AN UNSEEN HAND}

Scarcely a word has been written about the role of the solicitor in the history of criminal procedure. The topic goes unmentioned even in the standard works of reference, Stephen ${ }^{32}$ and Holdsworth. ${ }^{33}$ Three main explanations stand out.

\footnotetext{
32 Stephen, History.

${ }_{33}$ William Holdsworth, A History of English Law (16 vols. 1922-66) [hereafter cited as Holdsworth, $H E L]$.

The specialised monographs on the history of the solicitor's or attorney's profession also omit our topic. See, e.g., Michael Birks, Gentlemen of the Law (1960); Harry Kirk, A History of the Solicitor's Profession. 1100 to the Present Day (1976); Robert Robson, The Attorney in Eighteenth-Century England (1959). Brooks' careful archive-based study (n. 15 above) ends at 1640 , hence well before the relevant events.

Geoffrey Holmes' history of the professions includes a chapter treating lawyers that contains one passing mention of solicitors in criminal practice. Speaking of the period about 1730 Holmes identifies four men as "attorneys specialising in criminal cases, [who] were among eighteen leading London practicers who had chambers, and in some cases lodgings, in the Inner Temple." Geoffrey Holmes, Augustan England: Professions, State and Society, 1680-1730 (1982), p. 150. No source is cited, and I have not been able to trace the claim.
} 


\section{A. Unsettled Professional Patterns}

The profession of solicitor was still taking shape in the early eighteenth century, ${ }^{34}$ the period during which solicitors figured in the innovations affecting criminal procedure that are the centrepiece of this article. Solicitors were only then securing their ascendancy over the older profession of attorney, which they came to subsume. ${ }^{35}$ The attorney had been associated with the work of a single court, in connection with his role in entering pleadings. ${ }^{36}$ The solicitor first appeared in the fifteenth and sixteenth centuries, both to manage multi-jurisdictional litigation, ${ }^{37}$ and in connection with the factfinding needs of the "new courts and councils", especially Chancery, Star Chamber, and Requests. ${ }^{38}$

Indeed, into the nineteenth century "the solicitor was associated principally with the court of Chancery". ${ }^{39}$ Chancery (like the defunct Tudor courts of Star Chamber and Requests) adjudicated without jury trial, basing its judgment on the evidence that the parties gathered by means of interrogatories and other discovery. These courts had a vastly larger appetite for investigation into matters of fact than did the common law courts, which exhibited an opposite tendency. From the later Middle Ages into early modern times, the common law courts attempted to correct for the dangers of civil jury practice by narrowing their range of factual inquiry, employing such clumsy devices as single-issue pleading and the insistent preference for seal and record evidence. ${ }^{40}$ The testimonial disqualification of the parties at common law also greatly diminished the ability of the common law courts to find facts. ${ }^{4 !}$

The initial development of the profession of solicitor, and the solicitor's subsequent displacement of the attorney, occurred as part of the larger saga of Chancery's "conquest" 42 of common law. The

\footnotetext{
${ }^{34}$ Parliament supplied the regulatory base for the profession in the act of 2 Geo. II, ch. 23 (1729) ("for the better regulation of attorneys and solicitors"). The Act allowed only persons enrolled with one of the courts to sue out any writ or process, or to carry on any proceeding. See Holdsworth, $H E L$, vol. 12, pp. 52-57. This registration requirement produced records that make it possible to estimate the extent of the profession. It has been reckoned that London in 1730 had over 1,500 attorneys, or one to every 383 inhabitants. Philip Aylett, "A Profession in the Marketplace: The Distribution of Attorneys in England and Wales 1730-1800" (1987) 5 Law \& History Rev. 1, 3 .

${ }^{35}$ Holdsworth, $H E L$, vol. 6, pp. 456-457.

${ }^{36}$ Ibid. p. 453.

${ }^{37}$ Birks (n. 33 above), p. 88.

${ }^{38}$ Holdsworth, $H E L$, vol. 6, pp. 453-454.

39 lbid. p. 453.

${ }^{40}$ I have recently discussed these matters in John H. Langbein, "Historical Foundations of the Law of Evidence: A View from the Ryder Sources" (1996) 96 Columbia L. Rev. 1168, 1181-86, 1194-95 [hereafter cited as Langbein, "Evidence"].

4t Chancery purported to follow the common law rule of testimonial disqualification of the parties, see Holdsworth, $H E L$, vol. 9, pp. 194-195, but Chancery largely overcame the effects of the rule by facilitating party interrogatories and other discovery against parties.

${ }^{42}$ The expression is from Stephen N. Subrin, "How Equity Conquered Common Law: The Federal Rules of Civil Procedure in Historical Perspective" (1987) 135 U. Pennsylvania L. Rev. 909. The
} 
movement of solicitors into the work of investigating and managing criminal prosecutions was another manifestation of the expansion of the solicitor's profession from its base in Chancery. Having first appeared as evidence gatherers and litigation managers in Chancery and the prerogative courts, the solicitors gradually extended that model of legal representation into other jurisdictions, reaching the criminal courts in the decades under study in this article. Because these trends in the history of the solicitor's profession have not been much studied, we lack a background historical literature to help us relate the developments in criminal procedure to the larger pattern.

\section{B. The Paucity of Sources}

Solicitors were taking on the direction of the pretrial process in English criminal procedure in the early decades of the eighteenth century. Alas, pretrial procedure is barely in evidence in the law reports, the source from which our histories have mostly been written. The Anglo-American tradition in law reporting has been strongly oriented to appellate or en banc proceedings. Trial reports are rare, and "pretrial reports" unknown.

Other sources to evidence the investigative and preparatory work of the solicitor in the eighteenth century are also meagre. In general, contemporaries saw little reason to retain solicitors' investigative files or briefs to counsel. The useful life of such documents was short, especially on account of the dramatic finality of the criminal trial. The felony defendant in the eighteenth century was either acquitted, in which case he could never be retried; ${ }^{43}$ or he was convicted and usually executed or transported with dispatch. In either event, investigative documents generated by solicitors in the pretrial process had no further value and could be discarded. ${ }^{44}$

Enough scattered evidence survives, however, to permit us to sketch the solicitor's growing presence. The present article draws upon archive sources from a variety of governmental prosecutors; references culled from the State Trials and the Old Bailey Sessions Papers; and contemporary tract literature.

title of solicitor is said to have had a superior cachet to that of attorney, as a result of the solicitor's association with Chancery practice, where the clientele was wealthier. Birks (n. 33 above) at p. 144. For evidence from the period 1789-91 that Chancery litigation involved far larger amounts than suits at common law, see Douglas King, "Complex Civil Litigation and the Seventh Amendment Right to a Jury Trial" (1984) 51 U. Chicago L. Rev. 581, 606.

${ }^{43}$ See Hawkins, vol. 2, p. 368, $\$ 1$ (discussing autrefois acquit).

44 Many local record offices have holdings of solicitors' papers, usually deposited when a firm wound up its business. I have examined several such sets of papers. They contain abundant evidence of transactional and conveyancing work, but I have not found solicitors' briefs or other documents bearing on the work of solicitors in the criminal process in the first half of the eighteenth century. Michael Miles has found some traces of criminal practice in solicitors' records from later in the century, discussed below, pp. 334, 339-340. 


\section{Private Prosecution}

The scattered nature of the surviving records reflects the dispersion of responsibility for criminal prosecution. English criminal procedure, Stephen said somewhat tendentiously, "makes no provision either for the detection or for the apprehension of criminals. It permits any one to take upon himself that office, whether or not he is aggrieved by the crime. ..." 45

The English system did provide inducements, beyond mere civic virtue or the desire for vengeance, for citizens to shoulder the work of prosecution. The victim of a property crime often needed the help of a magistrate and constables to locate and recover his property, and the magistrate would typically oblige such a person to prosecute as a condition of assisting him with search warrants and the like. ${ }^{46}$ Nevertheless, the cost of bringing a criminal prosecution was a disincentive that worried policy makers throughout the century. Henry Fielding in his celebrated tract, An Enquiry into the Causes of the Late Increase of Robbers (1751), remarked that "the extreme Poverty of the Prosecutor" discouraged prosecutions. ${ }^{47}$ Even when the citizen prosecutor acted without the help of lawyers, wrote Fielding, the two shillings needed to pay the court clerk for the indictment was a hardship, as was the expense of several days attendance at court, sometimes distant from home. ${ }^{48}$

In the Continental procedural systems, in which the work of investigation and prosecution became a public and judicial function in the later Middle Ages, the creation and retention of records of criminal investigation became part of the bureaucratic routine of the courts. The Continental systems also developed a routine appellate stage for criminal cases, which reinforced the need to preserve investigative records. For these reasons, it is sometimes possible to

45 James Fitzjames Stephen, A General View of the Criminal Law of England (London 1863), p. 154. By Stephen's day this account had become anachronistic, on account of the growth of professional policing and the resulting movement towards police prosection. See generally David Philips, "A New Engine of Power and Authority': The Institutionalisation of Law-Enforcement in England 1780-1830", in V.A.C. Gatrell et al. (eds.) Crime and the Law: The Social History of Crime in Western Europe Since 1500 (1980), p. 155; see also Radzinowicz, History, vols. 2 \& 3.

46 The magistrates were required to bind over to testify at trial "all such . . . as do declare anything material to prove the . . Felony. ..." 2 \& $3 \mathrm{Ph}$. \& Mar., ch. 10 (1555). I have recounted the discomforts of a victim bound over in 1754 to prosecute at the Old Bailey, in John H. Langbein, "Albion's Fatal Flaws" (Feb. 1983) Past \& Present 96, 103-104. Sometimes the magistrate took an active hand in helping investigate felony. See, e.g., John Styles, "An Eighteenth-Century Magistrate as Detective: Samuel Lister of Little Horton" (1982) 46 Bradford Antiquary (NS) 98.

47 Henry Fielding, An Enquiry into the Causes of the Late Increase of Robbers (London 1751), in Malvin R. Zirker (ed.), An Enquiry into the Causes of the Late Increase of Robbers and Related Writings (1988), 61, 157 [hereafter cited as Fielding, Enquiry].

48 Ibid. pp. 157-158. Thus, it sometimes happened "that the poor Wretch who hath been bound to prosecute, was under more Concern than the Prisoner himself." lbid. p. 157. Fielding wanted more of the costs of prosecution to be borne by the public. From 1752, a series of acts began the process of providing more regular subsidy. See Beattie, Crime, pp. $41-49$. 
trace the investigative and charging phases of criminal cases in European countries in considerable detail. ${ }^{49}$ In eighteenth-century England, by contrast, there was a variety of prosecutors, mostly nongovernmental. They had scant reason to create or retain careful records. Solicitors seeped into the criminal prosecution, successfully offering their services to the nascent government departments and other institutional prosecutors, to citizen prosecutors, and to or through the justices of the peace and their clerks.

\section{The Prosecuting Solicitor in Action: Institutional Prosecution}

In the archive sources for the early decades of the eighteenth century, the prosecuting solicitor emerges most visibly in the service of a new breed of prosecuting authority. A number of government departments fielded an officer, actually labelled the solicitor, whose responsibilities included investigating and prosecuting criminal cases on behalf of the department. The Solicitor to the Mint, the Treasury Solicitor, the Solicitor to the Bank of England, and the Solicitor to the City of London have left evidence of their prosecutorial activity for the early eighteenth century. The Solicitor to the Post Office, who dates from $1683,{ }^{50}$ was also engaged, but his records do not survive until later. ${ }^{51}$

The appearance of these institutional prosecutors reflects important developments well beyond the law, including the changes in technology and in economic organisation that produced the Post Office and the Bank of England, as well as the greater elaboration of governmental departments from the Restoration onward. These institutions found themselves with an agenda to enforce parts of the criminal law. The Post Office needed to protect the mails both from robbers and from pilfering employees. The Bank of England prosecuted the forgery of its banknotes. The Royal Mint defended the currency against clipping and counterfeiting. The Treasury Solicitor exercised a general superintendence over royal interests in criminal prosecutions, especially in cases of sedition..$^{52}$

${ }^{49}$ E.g., Natalie Zemon Davis, The Return of Martin Guerre (1983); Michael Kunze, Highroad to the Stake: A Tale of Witchcraft (William E. Yuill, trans., 1987), translating Michael Kunze, Strasse ins Feuer: Vom Leben und Sterben in der Zeit des Hexenwahns (1982).

${ }^{50}$ Roger Williams, "The Post Office: 300 Years of Prosecuting" (April 1984) 13 The Retainer: The Journal of the Prosecuting Solicitors Society of England and Wales 13.

51 The earliest I have been able to locate is the solicitor's brief in $R$. v. Squat, P74/253 (1774), Post Office Archives, Mount Pleasant Street Sorting Office, London. Squat, a postal employee, was subsequently tried at the Old Bailey in July 1774 for having stolen money from the mails. At the trial, "Mr. Parkin, Solicitor to the Post-office" testified about his pretrial investigation in the case. OBSP (Jul. 1774, \#548), 401. (Squat was acquitted on one indictment but convicted and transported on another.)

52 In a forthcoming book, John Beattie reports that a second Treasury solicitor post had been created in 1696 to prosecute treason and coining, a post that became especially active in prosecuting cases arising from the 1715 Rebellion and related incidents. Beattie reports that from 
Several circumstances distinguished the task of the institutional prosecutor from the robbery victim, who was Sir Thomas Smith's prototypical citizen prosecutor. Because counterfeiting and offences against the coin did not victimise particular persons, the authorities could not count on citizen victims to shoulder the enforcement work. Furthermore, crimes such as embezzlement from the mails or forgery and alteration of banknotes entailed legal complexity, because the culprit often came into initial possession lawfully. ${ }^{53}$ Legal skill was needed to arrange for proper drafting of the indictment, and to identify and prepare witnesses to prove the elements of these offences.

Institutional prosecutors dealt with crimes that often required determined investigation to identify and apprehend the culprits, and to gather, preserve, and present the evidence of their deeds. Prosecuting in these circumstances required skill, effort, and resources, which is just what the institutions supplied. They arranged for a legally knowledgeable solicitor to administer what amounted to an enforcement budget.

\section{A. What Solicitors Did: The Mint}

The most useful archival record of early eighteenth-century prosecutorial activity that I have found comes from the Royal Mint. A class of document called Mint Office Record Books preserves periodic financial accounts from the Mint Solicitor from 1713. Because these accounts itemise steps taken in criminal cases that caused the Solicitor to incur charges for which he claimed reimbursement, ${ }^{54}$ they supply a window on his prosecutorial work.

The Mint Solicitor had an illustrious predecessor in his prosecutorial work, Sir Isaac Newton. Serving as Warden of the Mint

October 1714, two undersecretaries of state were named in the Middlesex commission of the peace, doubtless in order to give them magistrate's examining powers. John M. Beattie, Urban Crime and the Limits of Terror: Policy, Prosecution, and Punishment in London, 1660-1750 (Ch. 9) (forthcoming) [hereafter cited as Beattie, Urban Crime].

${ }^{53}$ On the development of the substantive law on these matters see Jerome Hall, Theft, Law and Society (2d ed. 1952) pp. 34-52.

\$4 Mint Office Record Book, Volume 8 (1699-1713), Public Record Office [hereafter PRO], Mint 1/8, at 115-120 "An Account of Expenses and Disbursements in the Prosecution and Conviction of Counterfeiters and Debasers of the Current Coin of this Kingdom and some others for uttering false Money knowing the same to be Such and other Law Charges attending the same in and about London, Westminster, Southwark, Essex and Kingston Assizes for two years, from Michaelmas 1713 to Michaelmas 1715").

The Mint records also evidence criminal investigations conducted on behalf of the Mint but not expressly attributed to the Mint Solicitor. "The Memorial of Henry Smithson," dated 25 March 1713/4, recites "[t]hat the said Henry Smithson hath been for near 14 years employed by the late and present Warden of the Mint in the apprehending and prosecuting" of counterfeiters. Mint Office Record Book, Volume 7 (1699-1728), PRO, Mint 1/7, at 64. Smithson was asking to have his bill paid. His "Account of [his] charges and Expenses" contains entries such as "Charges and expenses for my self, assistants and Horses in the pursuing and taking of Elizabeth Metcalfe, Francis Buckle . . . with others on Suspicion, of whom Elizabeth Metcalfe was convicted and executed and others fined and imprisoned. . . " Ibid. at 65 . 
in the years $1696-1699,{ }^{55}$ Newton found himself taking a leading hand in criminal investigations. ${ }^{56} \mathrm{He}$ chafed under this work and urged that it be assigned to lawyers. "'Tis the business of an Attorney and belongs properly to ye King's Attorney and Solicitor General, and they are best able to go through it especially with such assistance as they can procure." ${ }^{57}$ Later, as Master of the Mint, Newton acted on his inclination to lodge the work of criminal investigation and prosecution with lawyers. "In 1706 he secured a standing and larger allocation of public funds for the Mint's police work, and in 1715 he made its conduct less amateur by appointing a legally qualified man as extra clerk. . . . This Deputy Warden became Solicitor to the Mint. . . ." 58

The Mint Solicitor's main work was to investigate crime and gather evidence for trial. Sometimes the Solicitor investigated on his own, sometimes he worked with or through helpers. In developing the case against John and Elizabeth Barker, tried at the Old Bailey in 1714 for coining, the then Solicitor Richard Barrow spent money "attending the justices [that is, the magistrates, the justices of the peace who conducted the pretrial committal proceedings] and the witnesses who lived at Wapping and other far places." ${ }^{99} \mathrm{He}$ spent more "in inquiring after the [suspects] and giving money to persons for Information." Barrow then "[p]aid the constable for looking after the [seized counterfeiting] tools and letting them lie in his house", and "for a Box and a Basket Lock and Key" to secure them. He incurred additional "Expenses in going several times to Newgate to Speak to the persons to see if they would make discovery". In another case in 1715 Barrow's successor, Calverly Pinckney, claimed expenses "[f]or going into Surrey, finding out and taking Proofs from several Witnesses against" certain suspects," and for having "[p]aid one Woodward ... towards enabling him to make out his pretended Discoveries". ${ }^{60}$

The Mint Solicitor's efforts at detection and evidence-gathering led seamlessly into the work of preparing witnesses, framing and procuring indictments, and arranging for prosecution at trial. Barrow recorded that he prosecuted William Strange and James Robinson at Essex Assizes in March 1713 "for putting off counterfeit money". He

55 See John Craig, "Isaac Newton and the Counterfeiters" (1963) 18 Notes and Records of the Royal Society of London 136

s6 Newton's investigations are extensively evidenced in PRO, Mint 15/17, a collection of more than 500 "Depositions against or by counterfeiters sworn before Wardens, Mayors or Justices of the Peace, May 1698-May 1706, with a few letters and appeals to mercy to Wardens".

${ }^{57}$ Letter to the Commissioners of the Treasury, (No. 553), Jul./Aug. 1696, in J.F. Scott (ed.), The Correspondence of Isaac Newton: 1694-I709 (1967), vol. 4, pp. 209, 210.

${ }^{58}$ Craig (n. 55 above), p. 143.

${ }^{59}$ PRO, Mint $1 / 8$, (n. 54 above), at 118.

60 lbid. at $122,123$. 
paid the justices" clerk "for drawing the information and binding the Evidence over" and for drafting the two indictments. Barrow paid for the "expenses of Witnesses during the time of Trial at the Assize," and he "[g]ave the witnesses" a further $£ 1 / 10 / 0$. In this case Barrow engaged counsel, whom he paid both to advise on the indictments ("to peruse them"61) and to prosecute the defendants at the trial.

These four categories of expenditure-for investigation, for fees to clerks and other functionaries, for witnesses, and for counsel-recur in the Mint records across the eighteenth century.

1. Preparing witnesses. By mid-century the Mint accounts sometimes supply more detail about the Mint Solicitor's involvement with prosecution witnesses. In a counterfeiting case pending in Stafford in 1756, the Solicitor charged for "[a]ttending [five named persons] and other Witnesses to take the Substance of their Evidences," and then "[a]ttending [another named] witness to take the heads of His Evidence and service of a Subpoena on him" ${ }^{62}$ These contacts with witnesses were directed beyond detection, toward what we now recognise as the characteristic lawyer's role of selecting and preparing witnesses for trial.

2. Co-operation with the magistrates. In some cases the Mint Solicitor worked through the London magistracy, rather than conduct an investigation independently. In the case against John and Elizabeth Barker for coining in 1714 , previously discussed, ${ }^{63}$ the Solicitor recorded having attended the London magistrates. By mid-century, when the court J.P. system had brought the Bow Street magistrate to special prominence, ${ }^{64}$ the Solicitor made ready use of him. For example, in the investigation of Henry Lightouler and others in 1756, we find the Solicitor turning to John Fielding, the court J.P., for the arrest warrant. The Solicitor "examin[ed] him and [wrote up] his Information whereby he charged" various others. The Solicitor then

${ }^{61}$ Ibid. This expression appears often in the Mint accounts and elsewhere. In the Corporation of London Record Office (hereafter, CLRO) there survives a draft indictment in the case of Elizabeth Nichols, which was sent for review to counsel, John Tracy. Nichols was charged with malicious prosecution. Tracy suggested some changes, then wrote at the end of the draft, "I have perused and do approve of the draught of this indictment." His signature is dated 30 November 1743. CLRO, London Sessions Papers 1744, at 9. (I owe the reference to this file to John Beattie.) Tracy suggested a few drafting changes. At one point he inserted the words "with force and arms." In the margin he explained, presumably to the instructing City Solicitor: "I know there are precedents without those Words as well as others with them but as the Inserting cannot possibly do any Hurt and the leaving them out may furnish some little objection $\mathbf{I}$ thought it safer to Insert them." Ibid. at 6.

62 Mint Office Record Book, Volume 11 (1752-64), PRO, Mint 1/11, at 84 (account for 1755-56).

${ }^{63}$ P. 327 above.

${ }_{64}$ "Beginning at the latest with Sir Thomas de Veil, a former soldier who entered the Middlesex commission of the peace in 1729 , the government took to singling out one of the Middlesex J.P.s for special service in criminal investigation and prosecution. He received financial support, both in the way of compensation and in order to defray expenses. The person invested with this quasi-official status became known as the 'court J.P.,' 'court' in this usage referring to the central government." Langbein, "Criminal Trial”, p. 60. 
"[a]ttend[ed] Justice Fielding when [Lightouler] was further examined . . . and committed" ${ }^{65}$ On occasion the initiative flowed the other way. In the case of John Domine, for passing off counterfeit guineas, the Solicitor recorded: "On motion from Mr. Fielding, attend him when Defendant was examined and Committed". ${ }^{66}$

3. Financing criminal investigation. Part of what the Mint Solicitor contributed to investigation and prosecution was money. In Domine's case, the Solicitor paid for having the suspect's lodgings searched, where tools were found. ${ }^{67}$ Thus, Mint funds flowed through to support the Bow Street magistrate's band of thieftakers and constables, who amounted to a quasi-police force in the decades before London policing received a recognised basis. The Mint was not alone in subsidising the Bow Street force on a case-by-case basis. $^{68}$

In later periods as the Mint caseload grew, the Solicitor increasingly delegated the work of investigation and trial management to outside solicitors hired for each case. ${ }^{69}$

\section{B. Instructing Counsel}

During the early years of the eighteenth century the Mint Solicitor did not invariably employ counsel in the cases that he brought to trial. $^{70} \mathrm{He}$ was sometimes content to rely upon the witnesses to tell their own tales in the fashion of the ancient altercation-style trial. Across the decades, however, the employment of trial counsel in solicitor-directed cases became routine. Lawyerisation of the pretrial promoted lawyerisation of the trial. The solicitor who built a criminal prosecution by locating, selecting, and preparing witnesses wanted a legal professional to lead those witnesses at trial.

${ }^{65}$ Mint Office Record Book, Volume 11 (1752-64), PRO, Mint 1/11, at 90 (account for 1755-56).

${ }^{66}$ Ibid. at 97 .

${ }^{67}$ Ibid.

${ }_{68}^{68}$ In the slender Bank of England archive there survives for the year 1779 a bill from the Bow Street officers for their services in arresting the culprit and going to retrieve silver stashed at his mother's dwelling in Oxford. R. v. J. Matthison, Bank of England, F2/190 (1778-79).

69 By the 1840 s the Mint Solicitor had became a prosecutorial administrator, who placed most of the forensic work with outsiders. See Report of the Commissioners Appointed to Inquire into the Constitution, Management, and Expense of the Royal Mint (London, HMSO 1849) (copy preserved as PRO, Mint 2/17). Joseph Blunt, Solicitor of the Mint, testified to a Parliamentary committee about the work of his office. Ibid. p. 183 . He reported steadily increasing prosecutions and prosecution costs from the $1780 \mathrm{~s}$ to the $1840 \mathrm{~s}$. In 1786 the Mint brought 22 prosecutions at a cost of $£ 1,325$. In 1842 the Mint prosecuted 457 cases at a cost of $£ 10,744$. Ibid. p. 184. Blunt testified that he did not attend pretrial examinations or trials. He worked from the pretrial examinations taken by magistrates' clerks in order to "prepare briefs for the counsel. I draw a short analysis of the case, as a kind of brief, to attract the attention of counsel to the evidence, because without that they would have to hunt out what the different points were." Ibid. p. 189. The Mint hired local solicitors to manage the prosecutions. "[W]e usually prefer employing the gentleman who sends up the information; he is commonly the magistrate's clerk, and then if he is [an experienced] person . . I correspond with him about any deficiency in the evidence." Ibid. p. 192. For more on the overlap between magistrate's clerk and practising solicitor, see pp. 339-340 below; see also note 192 below.

${ }^{70}$ For example, none is recorded in the case against John and Elizabeth Barker, pp. 327, 328 above. 
In England the division between the two branches of the legal profession prevented the solicitor who had built the case from presenting it at trial. Only counsel had the right of audience at trial. (This division of function between solicitors and barristers, which is currently being rethought in England as the prosecutorial system adjusts to the creation of the Crown Prosecution Service, did not survive in the United States and in some of the other English-derived legal systems.) As late as 1724 there is evidence that the exclusion of solicitors from audience at trial was not as firm in English practice as it subsequently became. In the case of Edward Arnold, ${ }^{71}$ a deranged defendant tried for malicious wounding, the trial judge effectively allowed the defendant's solicitor to conduct his defence at trial. At the arraignment (the pretrial pleading phase in which defence counsel could be heard), Arnold's counsel referred to the client's impaired circumstances and asked that Arnold "may have a solicitor by him to call his witnesses only". ${ }^{72}$ Serjeant Cheshire, for the crown, opposed the request, invoking the familiar rubric of court as counsel. "Your lordship is of counsel for all the prisoners, who by law can have none, as this man can't have any." 73 The court allowed Arnold's solicitor to cross-examine a prosecution witness (the magistrate who conducted the pretrial committal hearing) and to present the defence case. ${ }^{74}$ (Arnold was convicted, sentenced to death, but reprieved to life imprisonment.)

Although Arnold's Case was undoubtedly exceptional, ${ }^{75}$ it shows experimentation as late as the mid-1720s with an alternative means of overcoming the rule forbidding defence counsel, that is, by allowing the solicitor rather than counsel to conduct the defence at trial. On the prosecution side, however, I have seen no indication of solicitors being given the right of audience at trial. ${ }^{76}$ Accordingly, the

${ }^{71}$ Edward Arnold, 16 St. Tr. 695 (Surrey Assizes 1724). The judge's instruction to the jury in this case became an early milestone in the development of the insanity defence. See Nigel Walker, Crime and Insanity in England: The Historical Perspective (1968), vol. 1, pp. 53-57.

7216 St. Tr. 697.

${ }^{73} \mathrm{Ibid}$. Three other crown counsel endorsed Cheshire's view, Ibid. pp. 697-698.

${ }^{74}$ E.g., ibid. pp. 714-715, 717. The "Solicitor for the Prisoner" called the accused's brother to testify about his mental state. The trial judge examined the witness, and prosecution counsel cross-examined. Ibid. pp. 717-718. Most of the questioning seems to have been done by the judge on the solicitor's motion, e.g. "My lord, I desire this witness may be asked" this or that, ibid. p. 737 (two instances), but on occasion the solicitor took over and conducted the examination himself, e.g., ibid. pp. 740-742.

${ }^{75}$ The judge, Tracy J, told the solicitor, "You have had an indulgence, the greatest that was ever given before. ..." Ibid. p. 743. Elsewhere the judge explained that it was "because there hath been an affidavit sworn, that he is not perfect in his senses" that the crown "gave liberty to another person to call the witnesses, and put what questions they pleased. . . " Ibid. p. 758

${ }^{76}$ Investigating solicitors did on occasion testify about their pretrial work. In the celebrated case against Samuel Goodere for murdering his brother, further discussed below, pp. 361-362, the prosecution solicitor, Jarrit Smith, was the first witness to be examined. Samuel Goodere et al., 17 St. Tr. 1003, 1017-26 (Bristol Assizes 1741). The Old Bailey pamphlet reports sometimes disclose the testimony of the Solicitor of the Mint in counterfeiting cases, e.g. Patrick Kelly, et al., OBSP (Jan. 1743, \#\#116-119), 70, 73; Johannah Wood, OBSP (Jul. 1746, \#274), 218, 219. 
solicitor who managed the pretrial proceedings needed to transmit his work product to the counsel who would present the case. This process of educating the barrister about the case came to be known as instructing counsel. The convention developed, which endures to the present, that the solicitor would prepare a document called a brief, summarising the case for counsel.

Prosecution briefs from the early decades of the eighteenth century are quite rare in the surviving archives. As with other evidence of the solicitor's pretrial work, the function of the brief was fulfilled at the trial, and thereafter no one had much incentive to preserve it. The Mint accounts sometimes show payments for preparing prosecution briefs. ${ }^{77}$ Among the records of other institutional solicitors, a few briefs exist. The Bank of England archives preserve some documents, including the brief, from the case of Robert Minor, accused in 1719 of presenting a forged bill of exchange. The Bank's directors ordered Minor prosecuted "if Mr. Woodford [the Bank's solicitor] shall think proper" (an indication of the internal delegation of authority to the solicitor characteristic of the increasingly complex organisations that appear as institutional prosecutors).$^{78}$

Woodford's two-page brief ${ }^{79}$ to counsel summarises the indictment, then provides a short statement of the charges (styled "The Case"). The main section, headed "To prove which Case", sets forth a series of factual propositions, for example, "To prove the handwriting of [the payee]", "To prove the forged bill is like the handwriting of Minors", and "To prove the tender of the bill". Alongside these propositions the solicitor entered the names of the witnesses who would testify in support of each point.$^{80} \mathrm{~A}$ still earlier brief, from 1702 , in the records of the City of London Solicitor, instances a more primitive version of this format. ${ }^{81}$

Prosecution briefs became more elaborate across the century. On

Oldham reports an incident in 1782 in which Lord Mansfield resolved to schedule a sitting of King's Bench on a date in Whitsuntide week that by custom was an adjourned date. When the barristers boycotted the sitting, Mansfield "made the Attornies conduct their own causes, and examine their own witnesses.'" James Oldham, The Mansfield Manuscripts and the Growth of English Law in the Eighteenth Century (1992), vol. 1, p. 75 [hereafter cited as Oldham, Mansfield Manuscripts] (quoting a newspaper account).

"E.g. in the case of Sarah Harris, the Mint Solicitor "paid for briefs and copies on trial". Mint Office Record Book, Volume 8 (1699-1713), PRO, Mint 1/8, at 116 (Kingston Assizes, 1713). In the prosecution of Amy Healy at York, Lent 1756 Assizes, for uttering counterfeits, the Mint Solicitor entered a payment for "Drawing brief." Mint Office Record Book, Volume 11 (1752-64), PRO, Mint 1/11, at 82-83.

${ }^{78}$ Bank of England v. Robert Minors, Bank of England F4/38/1 (1719). The file also contains a copy of the indictment, $F 4 / 38 / 2$, and a copy of Minors' pretrial examination, taken before William Thomson, the Recorder of London. F4/38/3.

${ }^{79}$ F $4 / 38 / 5$ (1719).

${ }^{80}$ Ibid. at 2.

${ }^{81} R$ v. Savage, CLRO, London Sessions Papers 1702, Miscellaneous Documents file (a case of criminal libel). (I owe this reference to John Beattie.) 
occasion the solicitor used the brief to advise the barrister on trial tactics. Regarding one prosecution witness whose anticipated testimony was discussed in a case for criminal malicious prosecution brought in 1741, the City of London Solicitor, Peterson, warned counsel of the danger that the defence

will produce the Record of [the prosecution witness'] Conviction for Conspiracy for which he was sentenced to stand in the Pillory. Please therefore against this to guard as much as possible. If in General they should attempt to impeach his character, we say that in such dirty work as a Conspiracy 'tis supposed None but persons of indifferent Characters are Consulted, and therefore such only can be produced as witnesses. But if his Testimony should be set aside, we hope the rest of our evidence will be sufficient to prove our charge. ${ }^{82}$

Peering through these rare windows into early lawyer-driven criminal cases, we see that lawyers inclined even then to the partisanship in fact gathering that is such a troublesome feature of the modern adversary system. The City Solicitor hoped to suppress the truth about his witness, but if that failed, he suggested a line of argument for downplaying the defect.

\section{Prosecution by the Executive}

Institutional reinforcement for criminal prosecution in the early eighteenth century also came on occasion from the monarch and the government.

In 1722 John Woodburne and Arundel Coke were convicted at Bury St. Edmunds of slitting the nose of Edward Crispe, a contemporary cause célebrè reported in the State Trials. ${ }^{83}$ The State Papers reveal that the king was offended at this "barbarous" offence (which had dignitary overtones). Concerned that the culprits might otherwise "escape unpunished", he directed the Attorney General to see to it "that able Counsel and a proper Solicitor be employed to attend that prosecution" at the king's expense. ${ }^{84}$ The Attorney General commissioned Nicholas Paxton ${ }^{85}$ to be the prosecuting

${ }^{82}$ R. v. Elizabeth Nicholls, CLRO, London Sessions Papers, September 1744, charged with maliciously accusing someone of a felony (the quoted brief dates from 1741 but is filed with documents from 1744 involving the same matter).

83 16 St. Tr. 53 (Suffolk Assizes 1722). The offence was made a capital offence (felony without benefit of clergy) under $22 \& 23$ Car. 2 , ch. $1, \$ 7$ (1670).

${ }^{84}$ State Papers Domestic Entry Book, PRO, SP 44/81, at 24 (entry for 5 Feb. 1722).

${ }^{85}$ Paxton was acting on behalf of the crown in another matter in 1722, advancing money to bring a prisoner down to London from the North. Ibid. at 139. A prosecution brief from Paxton dated June 1729 in an unrelated seditious libel case survives in the Treasury Solicitor's archive, PRO, TS $11 / 424 / 1290$. In the 1730 s Paxton appears to have been active on behalf of the crown in King's Bench prosecutions. E.g., PRO, SP 44/82, at 68, 69, 71, 72, 74, 76. John Beattie, who mentions Paxton's assignment in Arundel's Case (see Beattie, Crime, p. 354) identifies Paxton as the assistant treasury solicitor. For Paxton's role in prosecuting under the Black Act, see E.P. Thompson, Whigs and Hunters: The Origin of the Black Act (1975) pp. 212-213, cited by Beattie, p. 354 n. 92. 
solicitor. The two defendants were convicted. Paxton ran up a bill for $£ 85$, which doubtless included counsel fees. The Secretary of State directed the Treasury Solicitor to pay it. ${ }^{86}$

A year later the king intervened to arrange for lawyers to prosecute the suspected killers of a woman named Anne Bristol, whose violent death became a notorious case in the metropolis. Four men were charged with murdering her, allegedly in a gang rape. They denied the charges and contended that she had probably been killed when run over accidentally by a wagon. ${ }^{87}$ The king, "having much at heart that the four Watermen who murdered Anne Bristow on Smalbury Green in so barbarous a manner Should not escape unpunished", directed the Attorney General to "take this Prosecution under your Care, and appear at their Trials at the Old Bailey". ${ }^{88}$ The Secretary of State told the Treasury Solicitor of the King's pleasure "that you take care to procure the necessary Proofs, and to lay the same before $\mathrm{Mr}$. Attorney General, who is directed to take this Prosecution under his Management, and to appear at their trials at the Old Bailey". ${ }^{89}$ Despite the lawyers' efforts in the case, the jury was uncertain about what had happened and acquitted the defendants. ${ }^{90}$

Such episodic interventions in noteworthy criminal cases unrelated to affairs of state continued for decades. The government took charge of prosecuting the celebrated murder case of Mary Blandy, ${ }^{91}$ who was convicted at Oxford in 1752 of having poisoned her father in order to overcome his opposition to her romance. The prosecution brief survives among the Treasury Solicitor's papers, ${ }^{92}$ showing that Bathurst, the prosecuting counsel, spoke literally when he told the jury in his opening statement that "I am counsel in this case for the King, in whose name, and at whose expense, this prosecution is carried on. . ." ${ }^{93}$ Comparison of the published trial report with the solicitor's brief shows that counsel's opening statement closely tracked the solicitor's summary of the case in the brief, sometimes verbatim. ${ }^{94}$

We see in these cases the theme that John Beattie has emphasised, ${ }^{95}$

${ }^{86}$ State Papers Domestic Entry Book, PRO, SP 44/81, at 69, 119, 171.

${ }^{87}$ George Smith et al., OBSP (Apr. 1723), 1. Two medical experts testified in rebuttal to the defensive theory.

${ }^{88}$ State Papers Domestic Entry Book, PRO, SP 44/81, at 189, Townshend to Attorney General, ibid. at 189 (entry for 11 March 1723).

${ }^{89} \mathrm{Ibid}$. at 189 , Townshend to Cracherode.

OBSP (Apr. 1723), 3.

9118 St. Tr. 1118, 1120 (Oxford Assizes 1752)

${ }^{92}$ PRO, TS $11 / 854 / 2948$ (the prosecution brief and copies of the depositions from the pretrial committal proceeding).

9318 St. Tr. 1120.

94 E.g., counsel's statement at 18 St. Tr. 1126-27 contains verbatim paragraphs from the brief, PRO, TS/1 1/864/2948, at 1-14.

${ }_{95}$ John M. Beattie, Urban Crime and the Limits of Terror: Policy, Prosecution, and Punishment in London, 1660-1750 (Ch. 9) (forthcoming). 
the growing interest taken by the central authorities in the enforcement of the criminal law in the decades after the Revolution of 1688-1689. For present purposes the instructive point is that when the central authorities wanted to strengthen a criminal prosecution, they did it by sending in the lawyers. They employed solicitors to investigate and to plan the prosecution, and barristers to take the case to trial. As in the practice of the specialised institutions such as the Mint and the Bank, so in the episodic interventions of the central authorities, criminal prosecution was increasingly understood to be lawyers' work. In the light of this growing lawyerisation of prosecution, Hawkins' claim that criminal defence "requires no manner of Skill"96 looked ever more hollow.

\section{Solicitors in the Conduct of Private Prosecutions}

The lawyers' role in criminal prosecution in the early decades of the eighteenth century is harder to trace in cases brought on behalf of ordinary citizens. Citizen prosecutors lacked the resources and incentives to employ lawyers as routinely as the institutional prosecutors, nor did citizens share the interest or the capacity that the nascent bureaucracies were developing for preserving their papers.

By mid-century there is evidence of seemingly routine prosecutorial work in the financial ledgers of a prominent Bradford solicitor, John Eagle, who was active in the decades after 1759. We learn that he conducted six substantial criminal cases during his career. "97 "In April 1765 he handled a prosecution case against three defendants for stealing shalloons [wool lining material], malt, and silver spoons. $\mathrm{He}$ examined witnesses and drew the brief. The defendants were convicted at Pontefract Sessions and sentenced to be transported." 98 There is every reason to suspect that solicitors were doing such work earlier in the century, but the historical sources have not yet surfaced.

\footnotetext{
${ }^{96}$ Hawkins, vol. 2, p. 400.

97 Michael Miles, "Eminent Attorneys': Some Aspects of West Riding Attorneyship c. 1750-1800" (unpublished Ph.D. Thesis, Dept. of Modern History, Univ. of Birmingham, 1982), at p. 257. The account in text follows Miles; I have not inspected his sources.

${ }_{98} \mathrm{Ibid}$. p. 257, n. 2. The extract quoted in text is the only one of the six cases that Miles describes. The understanding that solicitors were by this time characteristically used to gather prosecution evidence is voiced in a pamphlet published in 1768 by an acquitted criminal defendant, James Oliphant. Oliphant was a surgeon who had been prosecuted for the murder of a servant girl whom he contended drowned accidentally. Oliphant alleges in the pamphlet that a vindictive coroner insisted on charging him and his wife with murdering the girl. Describing the coroner's exceptional industry in preparing the case against the Oliphants, the pamphlet complains "that he had become as a solicitor in this prosecution; that he had gone a hunting into the country after other witnesses than those who were examined on the inquest, to give evidence against the prisoners on their trial. . . ." Anon., The Case of Mr. James Oliphant, Surgeon, Respecting a Prosecution Which He... Underwent in the Year 1764 (Newcastle 1768), p. 49 (Beinecke Library, Yale Univ., shelfmark British Tracts 1768 Ol 4).
} 


\section{A. Old Bailey Practice in 1728}

The most valuable window that $I$ have found on the activity of solicitors working for private prosecutors in the early decades of the eighteenth century is an anonymous tract published in London in 1728, titled Directions for Prosecuting Thieves Without the Help of Those False Guides, the Newgate Sollicitors (sic) (hereafter, Directions) ${ }^{99}$ Although the author tells his readers that his "profession is not directly the Law", ${ }^{100}$ he was close enough to the London legal scene to dedicate the pamphlet to the influential Recorder of London, Sir William Thompson; and he was knowledgeable enough about criminal practice to devote the back half of the pamphlet to an exposition of the rudiments of criminal practice derived from Hawkins' Pleas of the Crown. ${ }^{101}$ A main theme of Directions is the superiority of counsel as advisers in criminal matters by comparison with solicitors. Even though the tenor of the tract is quite hostile to solicitors, the tract underscores the growing prevalence of solicitors in organising and preparing prosecution cases at the Old Bailey and in the lesser London criminal courts.

The author's announced "Design" is "to detect and put a Stop to the oppressive and dishonest Practices of the Tribe of Solicitors, in Prosecutions for Felony about this City. . . ."102 $\mathrm{He}$ laments the expense of engaging solicitors to prosecute at the Old Bailey. By driving up the cost, these "Newgate solicitors" worsen the victim's disincentive to prosecute. ${ }^{103}$ Because the victim is ignorant of the system, "the Matter is undertaken on the Solicitor's Terms", even though the solicitor's eventual "Bill is more unreasonable than a Tailor's. . . ."104 (The undertone that pervades this tract, that solicitors are duplicitous and disreputable, reflects an important strand of contemporary concern, which is further discussed in Part VI of this article.)

Directions depicts London solicitors as eager to sell their services. "[A] Solicitor makes Application to the Party robbed"105 to represent him. "When it gets into the public Papers that such a Person was

99 Anon., Directions for Prosecuting Thieves Without the Help of Those False Guides, the Newgate Sollicitors [sic] (London 1728) (Bodleian Law Library, Oxford Univ., shelfmark L.Eng.B.62.e.93) [hereafter cited as Directions]. I directed attention to this work in Langbein, "Criminal Trial", pp. 109 n. $441,127-129$ n. 511.

100 Directions, p. ii.

101 Ibid. pp. 14-27.

102 Ibid. p. ii.

${ }^{103}$ Ibid. p. 2.

$104 \mathrm{Ibid}$. p. 4 . The tract sets forth a sample bill from a solicitor for managing the case, mostly for pretrial work, which amounts to $\mathfrak{f 3} 8 \mathrm{~s}$. 9d. Ibid. p. 10. If "you do your Business without a Solicitor, the whole Prosecution of a Thief will cost you no more than two Shillings and four Pence". Ibid. p. 11. This sum, which is not explained, probably represents the clerk's fee for drafting the indictment.

${ }^{105}$ Ibid. p. 2. 
robbed ..., he is not many Hours without some of these officious Persons to advise him. ..." "106 The solicitor's early steps prepare for framing of the indictment. "[T]he Solicitor pulls out a Pocket-Book, takes the Name of the Prosecutor, the Parish of which he is an Inhabitant, and the Value of the Goods stolen . . ," and he takes special care to get the goods and the accused accurately described. ${ }^{107}$ Once again, the pamphlet deprecates the solicitor's contribution, asserting that anybody can do this work: "this, and much more, may be done without the Help of one of these Harpies. . .."108

The tract indicates something of the solicitor's role in preparing witnesses for trial. The "next Step is to make a great Stir in summoning all those together, who are to be Witnesses at the Trial of the Prisoner, and to direct who shall speak first, and how they shall deliver themselves to the Judge and Jury. . .."109 We find in this account a confirmation of the point previously inferred from prosecution briefs and other archive sources, that solicitors were already in this period taking an active hand in selecting, preparing, summoning, and sequencing the witnesses for trial.

Although Directions disparages the solicitor's pretrial activity as makework, that view seems nostalgic and unpersuasive. The author contends that the solicitor's preparation of witnesses is counterproductive: "nothing pleases the Judges more, than to hear Truth told with the utmost Simplicity and Plainness," rather than to have to preside over "the Proceedings and Villainy of sharping Solicitors. . .."110 Only "silly People are so ignorant as to believe they cannot be brought into Court, without being introduced by a Solicitor, nor be heard if they do not speak his Language more strictly than their own Sentiments. . ." I11 Indeed, "what is easier than to speak Truth, and what you know and saw, but not what others said, for that is no Evidence. ..." 112 These passages seem to echo for the prosecution Hawkins' argument about why the accused needs no counsel-that any defendant "of Common Understanding ... may as properly [defend himself] as if he were the best Lawyer",

106 Ibid. pp. 2-3.

${ }^{107}$ Ibid. p. 3.

${ }^{108} \mathrm{lbid}$. p. 3. In a similar vein, the author advises the victim "to give Instructions to the Person who draws up the Indictment", ibid. p. 7, who is said to be a clerk at the Guildhall or at Hick's Hall or in Westminster Hall, ibid. pp. 9, 27. The clerk "will readily assist you" if you give him the right information. $I$ bid. p. 9 . The prosecutor is better off without using a solicitor to inform the clerk, because (1) the clerks are more deferential to the solicitors, who tend to get the facts wrong; (2) solicitors are "perpetually tippling at the Expense of silly People" who hire them; and (3) "the Solicitor may be in Fee with your Prisoner to entangle you at the same time that he takes your Money, promising to exert the utmost of his Talents to [convict] the Prisoner. ..." Ibid. pp. 9-10.

109 Ibid. p. 3.

110 Ibid. p. 5 .

111 lbid.

112 lbid. p. 6. 
hence that "it requires no manner of Skill to make a plain and honest Defence. . ..":13

Directions does not describe solicitors instructing counsel, nor does it mention counsel acting at trial. The pamphlet implies that the role of prosecuting counsel at trial was still slight in 1728 . The trial judge is depicted as the examiner at trial, ${ }^{114}$ an expectation that would endure for decades. ${ }^{115}$ The pamphlet contains a sample bill ${ }^{116}$ from the solicitor to the prosecuting client that itemises the solicitor's services. The bill shows no entry for engaging counsel, although it records the solicitor charging for initial advice, for "examining and cautioning the Witnesses," for obtaining subpoenas (presumably to compel the attendance of prosecution witnesses), for "attending on the Prisoner to bring him to Confession," for "waiting at Hicks Hall" (a reference to the process of drafting the bill of indictment and securing its approval from the Grand Jury), and for "attending at the Old Bailey". "17 According to this source, therefore, the prosecuting solicitor in a victim-prosecuted case at the Old Bailey in 1728 was not yet routinely briefing counsel. The evidence of the Old Bailey Sessions Papers, already discussed, ${ }^{118}$ accords.

We see in this unique tract further support for the view that the main engine of lawyerisation of prosecution in the early decades of the eighteenth century was the solicitor, not the barrister, and that the lawyer's main sphere of influence was in the pretrial rather than at trial. Directions contends that the trend that it deplores to have solicitors manage criminal prosecution has become prevalent enough to sustain a full-time corps of London-area professionals. "I have known some Fellows," the author writes, "who have had nothing else to support them for some Years, but what they perfectly extorted from People [i.e. prosecutors] for Advice (and what may properly be called Mismanagement) at Guildhall, Hicks Hall, and the Old Bailey, in the time of the Sessions." 119

Although the tract's model bill for services presupposes that the solicitor would not ordinarily employ trial counsel, the author does recommend consulting counsel "when a Matter of great Consequence is to be tried [and] Advice is necessary". ${ }^{120}$ The author asserts that

\footnotetext{
113 Hawkins, vol. 2, p. 400.

114 Because prosecutors come to court nervous and long-winded, the judges must "draw the Circumstances of the Fact from them by a mild and gentle Method. . . "Directions, p. 13.

115 Dudley Ryder, newly minted as the Chief Justice of King's Bench and unfamiliar with Old Bailey practice, confided to his diary in 1754 that he planned "to come late some days at Old Bailey on purpose to be present when a trial being on I may hear how the judge sums up and examines witnesses." Quoted in Langbein, "Criminal Trial", p. 34

116 Directions, p. 10, discussed n. 104 above.

11 Directions, p. 10.

118 P. 318 above, regarding the relatively small number of recorded instances of prosecution counsel.

119 Directions, p. 12 (emphasis original).

120 lbid.
} 
"Counsel learned in the Law" will do the client "all the Justice the Merits of the Cause will admit of, yet the Charge will in the end be found less than employing a Newgate Solicitor, who in effect does nothing at all, but what might have been as well done, and very often much better, without him". ${ }^{121}$ The implication in this passage that solicitor and counsel were competitors in rendering "Advice" about how to try the case sheds valuable light on the role of lawyers in criminal procedure in this period. Although the author is partial to counsel and hostile to solicitors, he makes no mention of counsel having the exclusive right of audience at trial, an advantage over the solicitor that we would expect this author to have trumpeted had it mattered. I take the author's silence on this point as evidence that he still understood the lawyer's role in the prosecution of ordinary felony to be the job of pretrial management. The prosecution witnesses were still expected to speak at trial under the guidance of the judge and without the intermediation of counsel.

\section{B. Magistrates' Clerks as Prosecuting Solicitors}

The suggestion in Directions ${ }^{122}$ that solicitors came into initial contact with potential clients on the prosecution side by following up newspaper reports, whether or not accurate in some events for London, is not likely to have typified the patterns of engagement. A more regular channel for connecting the prosecutor with the solicitor was the justice of the peace (magistrate), to whom a victim would first come to report the crime and instigate proceedings. The magistrate often put the clerk in charge of the paperwork arising from the initial steps in bringing a criminal prosecution, that is, transcribing the pretrial examinations of the prosecutor and his witnesses, issuing warrants, and taking recognisances. ${ }^{123}$ It was common for the magistrate to employ as his clerk a person who practised privately as a solicitor or attorney. ${ }^{124}$ This early and official contact with inexperienced victims positioned the clerk on the inside track to be employed as the prosecutor's solicitor.

121 lbid.

122 Ibid. pp. 2-3, discussed pp. 335-336 above.

123 Regarding the magistrate's role in the pretrial process, see n.46 above. Model forms for (1) transcribing the examination of an accused, (2) taking a recognisance to bind a victim to prefer a bill of indictment and testify at trial, (3) binding a prosecution witness to testify, and (4) directing an arrest warrant to a constable are set forth in Richard Burn, The Justice of the Peace and Parish Officer (12th ed. 1772), vol. I pp. 527-528 (1st ed. 1755).

124 "All but one of the justices' clerks active [in Kent] in the last quarter of the [eighteenth] century are included in lists of attorneys resident in the counties-lists published for the first time in 1775": Norma Landau, The Justices of the Peace: $1679-1760$, at p. 229 n. 50 (citations omitted). Barnes notices the magistrates' clerks in private practice a century and a half earlier: Thomas G. Barnes, The Clerk of the Peace in Caroline Somerset (1961) p. 37. 
Michael Miles observed a little of this practice of the solicitor appropriating business from the J.P.'s parlour in sources for the later decades of the eighteenth century. Miles examined the records of the Yorkshire solicitor John Howarth, who was appointed clerk to the magistrate, Joshua Horton, in December 1769 and served him for a quarter century until Horton died in $1793 .{ }^{125}$ Howarth "was often the first person to be consulted on a whole host of complaints and problems", ${ }^{126}$ including potential prosecutions. Ledgers from Howarth's solicitor's practice show that he assisted one prosecutor in developing a case for violation of the game laws, taking the pretrial examinations of prosecution witnesses. ${ }^{127}$ In another case Howarth charged for preparing advertisements growing out of a robbery investigation (probably a case of highway robbery, hence advertising the reward). ${ }^{128}$ Miles reports that "Howarth's annual number of Quarter Sessions cases rose from nine in 1769 to 23 in 1770 on being appointed a Justice's clerk", ${ }^{129}$ and that "Howarth's yearly profits from conducting these prosecutions rose from an average of $£ 6$ in 1768 [before he was named magistrate's clerk] . . . to as much as $£ 34$ between 1770 and $1780 " .{ }^{130}$

When serving as the prosecuting solicitor, Howarth was exploiting an overlap that the system tolerated ${ }^{131}$ between the responsibility of the magistrate's clerk to develop the case ex officio and the solicitor's role as a service provider for hire. Howarth seems sometimes to have obtained the prosecutor as a client when the prosecutor approached him in his capacity as the magistrate's clerk. "[I]n these prosecutions, the person who made the accusation often approached Howarth first with details and witnesses, and [Howarth] then drew up the information or issued search warrants before going to the Justice at Howroyd." 132 Curiously, Howarth did not regard himself as precluded from doing defence work. Miles reports that "Howarth's Day Books reveal him advising both plaintiffs and the relatives of defendants in

125 "Howarth's yearly emoluments from this source ranged from $£ 68$ in 1770 to as much as $£ 151$ in 1778." Miles (n. 97 above), p. 267 (drawing upon Howarth's ledgers, called cash books).

${ }^{126} \mathrm{Ibid}$. p. 267. Howarth also advised potential civil and criminal defendants who had been summoned before other magistrates. Ibid. p. 268.

${ }^{127}$ Ibid. p. 268.

${ }^{128}$ lbid.

${ }^{129}$ lbid. p. 270. "His Assizes business, however, increased only slightly." lbid.

${ }^{130}$ lbid.

131 But see note 192 below, regarding the London Grand Jury Presentment of 1733, which denounced as an abuse the practice of magistrates' clerks charging fees of citizen prosecutors for steps taken as part of the magistrates' duties under the Marian pretrial procedure.

132 Miles (n. 97 above), p. 270. Thus, "[i]n August 1771 John Ferguson, an Halifax linen draper, came to Howarth with witnesses when Mary Firth had been detected in his shop stealing silk handkerchiefs. Howarth drew the informations [that is, the Marian pretrial examinations] of Ferguson and the two women witnesses and then went to Horton [the J.P.] at Howroyd." Ibid. p. 270, n. 3 (citing Howarth's manuscript day books). 
prosecutions for theft, coining, poaching and malicious damage, as well as conducting proceedings on their behalf". ${ }^{133}$

The pattern of having the magistrate's clerk serve as the prosecuting solicitor also occurred in institutional practice, where it lasted well into the nineteenth century. The Mint Solicitor told a Parliamentary committee in the 1840 s that "we usually prefer employing [as the solicitor to prosecute a case] the gentleman who sends up the information; he is commonly the magistrate's clerk. . . ."134

\section{Solicitors for the Defence}

John Howarth was not alone in serving sometimes as a solicitor for the defence. During the decades that solicitors were assuming an increasingly important role in the prosecution of crime, the profession also developed a defensive role in criminal cases. Once again, the sources are too thin to permit us to learn about the frequencies, but we can see the phenomenon in outline.

The rule forbidding counsel to the criminal defendant was a rule of audience in the trial court. For the out-of-court pretrial work of the solicitor no such prohibition took hold, although in the treason trials of the later Stuarts (where the law reports first notice ${ }^{135}$ the defence solicitor), we see considerable mistrust of solicitors who aided accused traitors. Fitzharris, one of the Popish Plot defendants in $1681,{ }^{136}$ complained of being denied access to his solicitor. ${ }^{137}$ When Stephen Colledge, another Popish Plot defendant, ${ }^{138}$ was observed at trial consulting his solicitor, Aaron Smith, the trial judge reprimanded

${ }^{133} \mathrm{Ibid}$. p. 270. "For instance, he advised John Holroyd of Marsden about the mode of prosecuting a person on suspicion of maiming three of his tups [sic.; male sheep]. In January 1770 Luke Dewhurst of Turvin was arrested for diminishing the coin, whereupon his wife consulted Howarth for advice. Similarly, he advised Mr. Taylor of Golcar Hill on his son being accused of killing fish. He also advised his tenant whose brother had been accused of coining and he appeared as his defence attorney at York Assizes in March 1770." Ibid. p. 270 n. 2.

134 Report of the Commissioners Appointed to Inquire into the Constitution, Management, and Expense of the Royal Mint (London, HMSO 1849) (discussed at note 69 above), p. 192.

135 In addition to the State Trials reports discussed next in text, there is a pamphlet report of a 1680 trial held at the Old Bailey, in which counsel, in his opening remarks, refers to his brief, that is, to the solicitor's brief instructing him in the case: "if my brief be true, I make no question but to satisfy your Lordship and the jury . . . that he had no hand in this Bloody Action." (Because the offence was charged as misdemeanour, the defendant was allowed counsel, the exception to the rule against defense counsel discussed p. 316 above.) The Tryal of John Giles at the Sessions House in the Old Bayly (London 1681) 30 (tried July 1680 for attempted murder of John Arnold, J.P. for Monmouth and M.P.) (Lincoln's Inn, shelfmark Trials 216 , no. 3 ).

136 Edward Fitzharris, 8 St. Tr. 243 (King's Bench 1681).

137 Fitzharris asked at his trial that "I may have a solicitor; for he was never allowed to come and speak to me, though I had a rule for him." 8 St. Tr. 329. The Lord Chief Justice replied that he let Fitzharris have a solicitor to assist him in briefing counsel to raise a point of law, but "now we are come to a matter of fact only, and we cannot by the rules of law allow you counsel. Therefore, what need you have of a solicitor, I cannot tell. . ." Ibid.

${ }^{138}$ Stephen Colledge, 8 St. Tr. 549 (Oxford Assizes 1681). 
Colledge: "How comes any body to give you papers? Nobody can solicit for one that is under accusation of High-Treason, unless he be assigned so to do by the court."139 The Attorney General, who was prosecuting Colledge, protested Smith's role in advising Colledge and in providing him with written notes and draft remarks. The Attorney General argued that Colledge's solicitor was effectively evading the ban on counsel by serving as an intermediary between the accused and counsel. ${ }^{140}$ The judges seized Colledge's papers and shared them with the prosecution. ${ }^{141}$ Stephen was still indignant about this manoeuvre two centuries later, calling it "one of the most wholly inexcusable transactions that ever occurred in an English court. . . ."142

The hostility to defence solicitors in the late Stuart-era State Trials was part of the larger pattern of disadvantage for treason defendants. Following the Revolution of 1688-1689, Parliament redressed that balance by enacting the Treason Act of $1696^{143}$ and by making provision for the independence of the judiciary in the Act of Settlement. ${ }^{144}$ The eighteenth-century State Trials show the courts voicing no objection to the defendant's use of a solicitor. Among the cases in which the report mentions the defendant having a solicitor are Richard Noble in 1713 for murder; ${ }^{145}$ John Matthews in 1719 for treason in printing a libel, ${ }^{146}$ and Christopher Layer in 1722 for treason. ${ }^{147}$ I have previously discussed the extensive latitude given to the defence solicitor in the notable trial of Edward Arnold in 1724 for malicious wounding. ${ }^{148}$ From the 1730 s onward, when the pamphlet reports of Old Bailey trials become more detailed, they

$1398 \mathrm{St}$. Tr. 571. (The term "assign" in this usage meant simply to authorise or permit the representation.)

140 If a solicitor is "permitted to go up and down and ask counsel of persons, and bring it in papers to the prisoner, it is the same thing as if counsel came to him. Here is a busy solicitor, and he gets advice from counsel, and then he delivers it to the prisoner. . ." $8 \mathrm{St}$. Tr. 583 .

$141 \mathrm{St}$. Tr. 584. "If I am ignorant what questions to ask of the witnesses," Colledge argued, why not let my friends help me formulate them? Ibid. p. 585. North L.C.J. gave the stock reply, invoking the court-as-counsel rubric (discussed p. 316 above). "We will sift out the truth as well as we can, you need not fear it." $8 \mathrm{St}$. Tr. 585 .

1421 Stephen, History, p. 406, noted in Holdsworth, HEL, vol. 6, p. 533 n. 11.

$1437 \& 8$ Will. 3 , ch. $3^{\circ}(1696)$, discussed p. 317 above.

14412 \& 13 Will. 3 ch. $2, \S 3$ (1701), discussed note 18 above.

145 Richard Noble et al., 15 St. Tr. 731 (Surrey Assizes 1713). "Mr. Lindsey, one of the attorneys concerned for the prisoners (for they had many) deposed that he" had drafted a subpoena for a witness, and sent a messenger to serve it in London, who had not yet returned. Ibid. p. 732.

146 is St. Tr. 1323 (Old Bailey 1719). Defence counsel Ketelbey, who was allowed to conduct a full defence under the Treason Act of 1696, made an opening statement in which he referred to the solicitor's brief. "[W]e shall, according to our instructions, be able to produce a great number of witnesses to contradict what these witnesses have sworn. . ." Ibid. pp. 1368-69.

147 Christopher Layer, 16 St. Tr. 93, (King's Bench 1722). Hungerford, defending, objected to the threatened reading of some papers by the prosecution, "though for my part I know not what they are, for there is no hint of them in my brief. . ." lbid. p. 199.

148 Edward Arnold, 16 St. Tr. 695 (Surrey Assizes, 1724); see pp. 329-330 above. 
occasionally show defence solicitors taking some action, such as explaining to the court the absence of witnesses or counsel. ${ }^{149}$

The institutional prosecutors could also find themselves fielding a solicitor for the defence when an agent or an officeholder was prosecuted for conduct in the line of duty. ${ }^{150}$ Indeed, the authorities occasionally trumpeted their willingness to defend citizen officeholders against civil and criminal suit as an inducement to zeal, for example, when the monarch ordered a crackdown on street crime in Covent Garden in $1742 .{ }^{151}$

\section{Associations for the Prosecution of Felons}

Another channel of engagement that placed criminal prosecutions under the management of solicitors was the association for the prosecution of felons. These remarkable organisations were formed in

${ }^{149}$ For example, in the case of William Kitchinman, OBSP (Sept. 1737, \#8), 165, accused of stealing calico cloth, his solicitor, Mr. Lutwych, tried unsuccessfully to have the trial postponed, telling the court, "The Prisoner's Sister gave me Money for Counsel and Subpoenas against tomorrow," and that "I gave Subpoenas to Mr. Dottery and his Wife, but I did not imagine his Trial would have been till tomorrow." Ibid. at 166. In the case of John Latour, OBSP (Sept. $1736, \# 75$ ), 186, the defendant told the court that "his Attorney had engaged Counsel in his Cause; but the Prosecutor sent notice to him last Night, that the Matter was compromised, and that this was the Reason he had no body to appear for him." Ibid. at 188 . Mr. Compton, identified as Latour's attorney, confirmed this account and "was much surprised when I found Mr. Latour was called to his Trial; if I had known it, I should have feed [that is, paid a fee to, meaning hired] Serjeant Haywood. I had Instructions to call [a witness to speak to a key issue of factl if I had been prepared." Ibid.

${ }^{150}$ An 1803 committee of inquiry into the work of the City of London Solicitor traced the office back to 1545 and reported that "he has been employed to defend the magistrates and officers of this city in proceedings instituted against them for acts done in the execution of their respective offices and the discharge of their several duties. . . "Report in Relation to the Nature, Duties, and Emoluments of the Office of City Solicitor. CLR0, PAR (Papers, Acts \& Reports) Book 13 (Common Council, 27 July 1803), at 3.

The Post Office archive, at P74/271, contains a brief titled "The King against Read: For Felony. Brief for the Prisoner", prepared in 1793 by Parkin \& Lambert, which was the firm of Anthony Parkin, who was then the Post Office Solicitor. The Post Office was defending an employee, a guard on the Exeter mail coach, who had fired a weapon in purported defence of the coach. The OBSP pamphlet report contains the trial and records Read's acquittal but does not disclose the appearance of the defence counsel whom the Post Office Solicitor briefed. Patrick Read, OBSP (Jan. 1793, \#128), 199.

is In December 1742, the King had Newcastle write to the chairman of Westminster Sessions, to convey royal interest in cleaning up the Covent Garden area. PRO, SP 44/82, Criminal Book, 17 December 1742 , at p. 188 . He wrote that

Covent Garden is infested with great Numbers of reputed Thieves, Pick-Pockets and other desperate Persons, who have formed themselves into Bodies, so that it is hazardous and dangerous for Persons of Quality to pass and repass to the Playhouses and other Parts thereabouts, without being assaulted and rebbed. His Majesty, who is desirous to encourage the Suppressing of such wicked Disorders, has commanded me to acquaint you, that Orders shall be given to the Solicitor of the Treasury to defend, at his Majesty's Expense, all Constables, and other Peace Officers of the said City and Liberty in any vexatious actions, or Suits at Law, that may be brought against them, for what they shall do in the faithful Discharge of the Duty of their Offices, in putting in Execution the Warrants issued to them by the Justices of the Peace, for the purposes aforementioned.

Ibid. at 188-189. It was hoped "that the apprehension of Trouble and Expense on this Account may not discourage them from carrying on a Service so important to the Peace and Security of his Majesty's Subjects." Ibid. at 189. 
uncounted profusion through most of England. The earliest known examples date from the $1690 \mathrm{~s}$. The organisations were especially characteristic of the decades after $1770 .{ }^{152}$ They declined in the middle of the nineteenth century, when official policing and police prosecution effectively displaced them. Estimates of the total number of prosecuting associations range from $1,000^{153}$ to as many as $4,000 .^{154}$ Many associations were short-lived, ${ }^{155}$ others functioned for decades; indeed, a handful still survive as provincial dining societies.

Among the reasons that the associations interest us is that they help correct for the London bias of much of the rest of the sources for the history of criminal prosecution in the eighteenth century. Although some prosecuting associations formed in the cities, ${ }^{156}$ most operated in provincial areas and had a special emphasis on rustic crime such as the theft of horses, livestock, and crops-for example, the 1770 "Articles of Association and agreement . . . by several Gentlemen, Tradesmen, Farmers and others of the County of Nottingham, To prosecute Horse Stealers for offences committed in the said county". ${ }^{157}$

The associations aspired to promote the enforcement of the criminal law by spreading the costs of investigation and prosecution among the membership. One of the earliest surviving association agreements, from Maghull, Lancashire, recited in 1699 that the association was being formed in response to the danger that persons who committed serious crimes might "escape prosecution and punishment by reason of the charge and expense that would be occasioned in case the owner of the goods stolen should prosecute such felons by due and legal courts of law". ${ }^{158}$

152 See the chronological table in David Philips, "Good Men to Associate and Bad Men to Conspire': Associations for the Prosecution of Felons in England 1760-1860", [essay hereafter cited as Philips, "Associations"] in Douglas Hay \& Francis Snyder (eds.) Policing and Prosecution in Britain 1750-1850 (1989), pp. 113, 161-166 [volume hereafter cited as Hay \& Snyder].

153 Ibid. p. 120

${ }_{154}$ P.J.R. King, "Prosecution Associations and Their Impact in Eighteenth-Century Essex", [essay hereafter cited as King, "Essex"] in Hay \& Snyder, pp. 171, 173 n. 8.

155 Ibid. p. 180 (in the studied Essex sample "half of those formed before 1785 do not seem to have survived the century").

156 Examples of the work of the London Society for Prosecuting Felons from the year 1795 are discussed in Langbein, "Criminal Trial", pp. 127-129.

${ }^{157}$ Nottingham County Record Office, DD.T. $25 / 1$ (24 Oct. 1770).

${ }^{158}$ Maghull Agreement for the Prosecution of Felons, dated 21 July 1699 , extracted in Adrian Shubert, "Private Initiative in Law Enforcement: Associations for the Prosecution of Felons, 1744-1856", in Victor Bailey (ed.) Policing and Punishment in Nineteenth Century Britain (1981), pp. 25, 26 (attributed to Lancashire Record Office, PR 2814/1) [essay hereafter cited as Shubert, "Initiative"].

Shubert describes a similar statement of purposes from the Bretherton Association in 1744. Its articles recite that "diverse burglaries and felonies have of late years been committed," yet "prosecutions are not carried on against the offenders with so much vigour as ought to be on account of the great expense attending such prosecutions. . ." Ibid. p. 26, citing Lancashire Record Office 2851/12/1. The result is that "persons from whom goods are stolen often acquiesce and do not endeavour to find out or prosecute offenders by reason of the great expense attending such prosecutions, by which means they go unpunished." Ibid. 
The associations have recently attracted the attention of legal historians. ${ }^{159}$ Although the link between the associations and the solicitor's profession has not been a central concern of this literature, enough has been learned to permit us to see that the associations were a main conduit for the lawyerisation of criminal prosecution in the eighteenth century. Unfortunately, little is known about the work of the associations in the early decades of the century, the period of particular interest in the present article. The archival record is extremely thin until the second half of the century, and thus, our picture is mostly drawn from sources that are later than we would wish.

As the name implies, the prosecuting associations were voluntary organisations of a sort now sometimes characterised as mutual benefit insurance societies. Members who pay a subscription fee become entitled to scheduled benefits. My automobile club, for example, will tow my car or charge the battery if the breakdown occurs within the year of my subscription. The association not only provides these specialist auto repair services, it also serves an insurance function. Because not all members will actually require the covered services, the association operates as a risk pool, spreading the cost of the services it performs across the larger number of persons covered. This cost-spreading feature allows the association to deliver the services well below unit cost to the members who receive them.

The association for the prosecution of felons was a benefit society for the purpose of bearing some of the costs associated with the risk of being victimised by a serious crime. Members adopted articles of association and paid a subscription. When a member suffered a crime of a type covered in the articles, the association would pay the expenses of criminal investigation and prosecution. It would advertise stolen goods and offer rewards for the return of goods and the apprehension of culprits. Sometimes the articles of the association contained a schedule of rewards to be offered and paid to persons "giving such information against such offenders as shall lead to his or their conviction. ..." ${ }^{160}$ (These extra-statutory rewards are to be distinguished from the statutory $£ 40$ rewards paid by the crown for certain offences pursuant to legislation, discussed below in Part VII of this article.) Some of the associations also functioned as indemnity funds, insuring members against part of the loss that resulted when

159 David Philips' study of the period $1760-1860$ is a particularly valuable survey. Philips, "Associations", (n. 152 above). See also King, "Essex", (n. 154 above); and Shubert, "Initiative", (n. 158 above).

${ }_{160}$ Rules and Orders of the Binbrook Association for the Prosecution of All Persons Who Shall be Guilty of Felonies, Thefts, Crimes, or Misdemeanours (Louth 1820) (printed handbill) (exemplar in Lincolnshire County Record Office, shelfmark 4 BM 5/5/2/2). 
the stolen goods were not recovered. ${ }^{161}$ Finally, when the culprits were identified, the association absorbed part or all of the costs ${ }^{162}$ of gathering evidence and bringing prosecutions.

The feature of particular importance for purposes of the present essay is that by the second half of the eighteenth century (when the sources become ample) the associations were routinely managed by solicitors. The association's secretary or treasurer was usually a solicitor, often named in the articles of association. ${ }^{163}$ Although some associations left it to the member to institute prosecution and seek reimbursement for expenses incurred, ${ }^{164}$ the model that prevailed recast the association as the service provider, arranging for the association's managing solicitor to conduct the investigation and prosecution. For example, the Binbrook (Lincolnshire) Association's articles designated Thomas Rhodes of Market Rasen as treasurer "and also secretary and solicitor for conducting prosecutions", and allowed him "out of the funds of this Association his fees of office, and all other reasonable charges for extraordinary trouble relating to the affairs of this Association". ${ }^{165}$ David Philips, summarising a study of more than 200 sets of association records dating mostly from 1760 or later, observes:

The solicitors invariably benefited most financially from the associations: they received a regular retainer from the society,

161 E.g., Rules and Orders of the Fakenham Association Against Horse-Stealers (Norwich 1782), at pp. 8-9 (Lewis/Walpole Library, Yale Univ,, shelfmark 767So5) (providing that three months after the loss occurred the association would pay the value of the horse, to a ceiling of $£ 20$ ). The Nottingham association, discussed supra note 157 , paid the owner half the value of the horse to a ceiling of $£ 13$, one year after the loss. Nottingham County Record Office, DD.T. $25 / 1$, art. 5 (24 Oct. 1770).

162 Sometimes the association's articles provided general authority for reimbursement, for example, in "Rules of the Linton, Hildersham, Bartlow and Hadstock Association for the detection and prosecution of Felonies and Misdemeanours", (20 Nov. 1818) art. 2: "All reasonable Expenses which may be incurred in apprehending and prosecuting Offenders against Subscribers to this Association, shall be paid out of the Common Stock. . . "Cambridgeshire Record Office, L95/ 18/1. Other associations devised preset reimbursement schedules. The Binbrook Association (n. 160 above), art. IV, p. 4 (1820), promised to reimburse members four pence per mile "[f]or every prosecutor's and witness's horse-hire in going to any magistrate or court," five shillings per day "[f]or every male witness's time, trouble, and expenses," and four shillings per day "[f]or every female witness's time, trouble, and expenses. . ."."

${ }^{163}$ For example, the articles of the Nottingham association, (n. 157 above) designated the solicitor Job Brough as the person to whom members should report a covered loss, ibid, art. 3, and directed him to invest any surplus funds "on Government Security". Ibid., art. 6. When Brough died in 1795, the association's journal recorded that "Messrs. Pocklington and Company, Bankers in Newark" would replace him as treasurer; and that Edward Smith Godfrey and Benjamin Joseph Smith were "appointed Agents and Solicitors to the Association". Ibid., entry for 1795 .

${ }^{164}$ Shubert reports that the articles of the Turton Association in Lancashire carefully spell out that the prosecutor was left "to take upon himself all the trouble of prosecuting and providing all the proper evidence ... as if prosecuting at his own charge." Shubert, "Initiative", p. 32 (citing Lancashire Record Office, UDTu19). Philips dates the founding of the Turton Association to the year 1789. Philips, "Associations", p. 163.

${ }^{165}$ Binbrook Association (n. 160 above), art. 11, pp. 7-8 (1820). 
and they handled all its business, taking members' reports of offences committed and handling the subsequent prosecutions, advertising the society and its members, and collecting subscriptions. Reading through their itemised accounts (each interview at $3 s .4 d$. or $6 s .8 d$. a time, which quickly mounted up) one sees how good associations were for their business. ${ }^{166}$

Entries like the following, from the annual bills filed by the solicitor to a Bedfordshire association active from 1799, abound: "Paid printer and distributing bills [regarding] . . . Mr. Burton's Mare." "Clerk's Journey to Newport to learn the names and residences of two Men who were suspected to have stolen the mare." "Journey to Turvey to examine Evidence as to Bacon stolen from Mr. Brattams by Thomas Norman." "To Counsel and Clerk with Brief in the Prosecution of Thomas Hawkins for Stealing Wheat Stacks from Mr. B. Brooks of Emberton." "Attending Mr. Griggs and others and taking instructions to prosecute Marshall for stealing Meal." "Paid Expenses of the several Witnesses to and from and at Aylesbury on the prosecution of Marshall." 167

In these records we see the lawyers taking over an important segment of the work of criminal investigation and prosecution in the provinces. From the standpoint of the solicitor, a prosecuting association was a dream client. The solicitor fed off the retainer for the society's routine administration, and he captured its investigating and prosecutorial work. The association also brought the solicitor into steady contact with the substantial citizens who constituted the association's membership, among whom he could prospect for other business. Indeed, there is every reason to believe that the initiative in creating these associations passed from the citizenry to the solicitors' profession. John Styles has reported in this connection that "a Yorkshire attorney's precedent book from the 1750 s includes . . . an agreement [establishing an association to prosecute felons], suggesting that they were already part of an attorney's work at that date". ${ }^{168}$ Philips noticed indications that solicitors "were the most active promoters of associations, urging local property-owners to set them up; and many [solicitors] acted as solicitor to more than one association". 169

To conclude: The evidence is unmistakable that in the second half of the eighteenth century and beyond, the associations for the

${ }^{166}$ Philips, "Associations", pp. 136-137.

167 Olney, Turvey \& Harrold Association, Bedfordshire Record Office, GA 1108 (solicitor's bills, loose pages, filed by date from 1799), entries for 1799, 1800, 1808 .

168 John Styles, "Print and Policing: Crime Advertising in Eighteenth-Century Provincial England", in Hay \& Snyder, pp. 55, 64 [hereafter cited as Styles, "Advertising"].

${ }^{169}$ Philips, "Associations", p. 137. King reports that the Essex "attorney, William Mason, ... acted as clerk to at least five prosecution associations in the north-east of Essex." King, "Essex", p. 192. 
prosecution of felons served as important conduits for the lawyerisation of criminal investigation and prosecution in provincial centres and in the countryside. The archival record for the early decades of the century is too thin for us to know when this phenomenon became significant. If by the 1730 s the associations were already beginning to influence the criminal prosecutions coming before the courts, their contribution to the legal-professional transformation of criminal prosecution would have been among the factors that the judges were weighing as they rethought the rule against defence counsel.

\section{The Ill Repute of Newgate Solicitors IN THE 1730s}

This article has traced the development of evidence-gathering and case management by lawyers, especially for the prosecution but also for the defence. In Continental legal systems such work was done by officers of the courts, that is, by judges and subordinate examiners. In England, where court-conducted fact-gathering did not develop, the work of criminal investigation fell to private lawyers hired by interested parties. We see in the English developments of the eighteenth century a central chapter in the history of what would become the Anglo-American adversary system of criminal procedure.

The central flaw of adversary criminal justice is that it leaves the work of fact-gathering to persons whose interest is often not aligned with exposing the truth. Partisan lawyers are hired to serve the interests of their clients. Their incentive is to win. Our combat-based system of procedure can easily point away from truth, towards suppressing, distorting, altering, or falsifying evidence.

Already in the 1730s, when the English bench made its epochal decision to allow defence counsel to probe prosecution evidence at trial, the historical sources manifest a growing uneasiness about the reliability of the evidence that lawyers were generating, as solicitors for the prosecution and the defence.

Disquiet about the potential for solicitors to defeat the truth can be found in the English tract literature as early as 1681, when an anonymous broadside published in London complains that " $[\mathrm{t}]$ here is much cunning in procuring and tampering with witnesses, and much art in packing of Jurors. . ." 170 The writer poses the question, "May not a man meddle with or question a Witness?" The answer given is, "Yes, But with certain limitations. Otherwise a Witness may be made or corrupted, Judges and Jurors abused, and the Innocent utterly

170 Anon., Seasonable Cautions for Juries, Solicitors and Witnesses; To Deterre from Man-Catching (London 1681) (Wing S 2222), p. Ir (exemplar in Huntington Library, Los Angeles, CA). 
destroyed." $" 171$ The writer wrestles with the boundaries of correct professional practice, approving of pretrial investigation but voicing concern lest the solicitor corrupt the witnesses. "A Solicitor . . . may not instruct, threaten or bribe [witnesses] to swear this or that."172

Directions, the 1728 pamphlet critical of London prosecuting solicitors, warns of the danger that in cases in which there is a statutory reward for conviction, solicitors would strain to exaggerate the case in order to bring the offence within the rewardable category. Thus, "by the Insinuations of the Solicitor, and the Covetousness of the Prosecutor, Truth would be perverted. . . ."173 Sir Isaac Newton, writing to the Treasury in 1696, complained that his prosecutorial work as Warden of the Mint exposed him to the "calumnies of . . . Coiners and Newgate Solicitors," who made "false reports and oaths and combinations against me". ${ }^{174}$

\section{A. Misbehaving Solicitors}

In September 1732, in the prosecution of Peter Buck for highway robbery, ${ }^{175}$ we find the script that the author of Directions warned about, namely, a solicitor orchestrating a false prosecution for gain. Joseph Fisher, the ostensible victim, testified that Buck forcibly stopped hịm in Chancery Lane and robbed him of his snuff box. The defendant's sister testified that the prosecution resulted from a failed shakedown organised by one "Lawyer Grimes", who "solicits in this court". In advance of the trial Grimes had met with her and introduced her to Fisher as "a Man that will swear a Robbery against [her brother]". (Highway robbery was an offence for which a $£ 40$ reward was payable to the persons who convicted the offender. ${ }^{176}$ ) Grimes told the sister that, if she "would save [her] Brother's Life", she needed to pay off both Grimes and Fisher. Grimes wanted three pounds in payment of a supposed debt that the brother owed Grimes, and a further two guineas for. Fisher. Fisher told her that "if you'll satisfy Lawyer Grimes, and give me 2 Guineas, I'll make it up", that is, drop the prosecution. ${ }^{177}$ Another witness testified that Fisher admitted ruefully to her a few days before that he had sworn falsely against Buck, and that "Lawyer Grimes put me upon it". ${ }^{178}$

\footnotetext{
$17 \mathrm{Ibid}$.

172 Ibid. The passage in text continues: "He may discourse with them, and enquire whether they have any thing to say to this or that point, in order to save the Court a trouble; but he ought not to work them by hope of reward, or fear of harm to say more, or less than they are inclined to. ..." After framing the issue in this way, the writer devotes the remainder to sermonising about the evils of false witness.

173 Directions (n. 99 above), p. 4. He gives the example of overcharging as highway robbery what "was only a Quarrel between the Prosecutor and the Prisoner." lbid.

${ }^{174}$ Letter to the Commissioners of the Treasury, note 57 above, p. 210.

175 OBSP (Sept. 1732, \#53), 210.

1764 \& 5 Will. \& Mar. ch. 8, $\$ 2$ (1692).

in OBSP (Sept. 1732, \#53), 210.

178 Ibid. 211.
} 
The trial judge ordered Grimes brought into court, "reprimanded him, and forbad him ever to Practise in that Court for the future". 179 The jury acquitted Buck on the spot, but discussion of Grimes continued. One of the jurors told the court: "My Lord, we have taken Notice of his being very busy with the Witnesses all this Sessions." Someone named Robert Nash told the court that Grimes "makes it his Business to set People together by the Ears and foment Law-Suits", and that Nash had paid off Grimes to spare a lawsuit. Someone identified as "A Juryman's Wife" volunteered that "Lawyer Grimes keeps a public Bawdy-House in Church Yard Alley. . .."180 The trial judge replied to these allegations that "Those who know these Things should indict him as a common Barretor, and for keeping a common Bawdy-House". ${ }^{181}$

Grimes was a hard man to put out of business, however. A few days later, the reporter tells us, "Mary Tompson, a Juryman's Wife, informed the Court upon Oath", that Grimes approached her outside the courthouse door, took her aside and talked to her about the case of Henry Davis, who was to be tried for Burglary (another of the offences for which legislation promised a $£ 40$ reward for conviction). Grimes told her: "'[W]hisper your Husband to tell the rest of the Jury, that if they will find [Davis] guilty of the Indictment, they shall have two Guineas a piece." 182 The report continues: "Upon [hearing] this the Court immediately granted a Warrant for apprehending the Lawyer." 183

The same September 1732 sessions of the Old Bailey that heard these reports of Grimes' efforts to bring a false prosecution and to bribe a jury also dealt with a case involving the abuse of coaching witnesses. In the case of James Lewis, ${ }^{184}$ for forging a will, prosecution counsel appeared and stated the case against him. It was alleged that Lewis was a moneylender to sailors, whose practice was to require the sailor to execute a will in his favour before making the loan. In this case, prosecution counsel claimed, the accused forged a sailor's will after the death of the sailor. Witnesses were brought to testify about when the will was signed. One Joseph Wass, apparently serving as the prosecution solicitor, was overheard telling one of the witnesses

\footnotetext{
${ }^{179}$ Ibid. The report identifies Grimes as alias John Graham.

$180 \mathrm{lbid}$.

181 Ibid.

182 lbid.

${ }^{183}$ Ibid. Grimes was involved in a yet another questionable prosecution in the September 1732 sessions, under his alias, as John Graham. In the case of Ann Foster, OBSP (Sept. 1732, \#20), 180 , who was accused of stealing a pocket book containing promissory notes, the prosecuting victim had advertised the lost items. He told the court that he had Foster arrested and prosecuted after John Graham came to him and told him that Foster had his pocket book. Foster was acquitted after presenting evidence that she found the items.

184 OBSP (Sept. 1732, \#17), i 78.
} 
to say that the decedent signed the will on 30 November. An unidentified "Officer" interrupted the trial and advised the court, "My Lord, here's this Man, Joseph Wass, [who] prompts the Witnesses." 185 An unidentified "Gentleman", apparently a bystander who overheard Wass, volunteered the same information. The judge ordered them sworn and asked them what they heard Wass say. Each testified that Wass told them what date to say. Wass defended himself: "Suppose I did, I hope there was no Harm in that." The judge exploded: "No harm, Sir? When a Man's Life is at Stake, are you to put Words in the Witnesses' Mouths, and direct them what to swear? Officer, take him into Custody." 186 Here, on the eve of the judges' decision to admit defence counsel to cross-examine witnesses, is an Old Bailey judge recognising the danger that solicitors may "put words in the Witnesses' Mouths, and direct them what to swear. ..."

We have seen that Directions, the 1728 pamphlet critical of prosecuting solicitors at the Old Bailey, makes several allegations of duplicity. One is that the prosecuting solicitor "will often, for a Fee from the Prisoner, advise the Prosecutor to compound the Felony before Sessions, or not to appear at the [trial], for which [the prosecutor is himself theoretically] liable to a Prosecution. . . ."187 Some years later, in 1741, the Old Bailey reporter disclosed such a case, a prosecution for highway robbery in which the victim, Parish, testified that after the robbery, "I not knowing how to proceed, a Fellow, one Baker, offered me his Assistance as an Attorney, and got a Bill of Indictment drawn according to his own Way of Thinking; I paid him 2 shillings for it, and he has dropped me, and keeps the Indictment." 188 Later in the trial, Baker appeared as a defence witness, claiming that Parish had been unable to identify the culprits at the time of the crime. "The Court severely reprimanded Baker for his Conduct in this Affair." 189

185 Ibid. 179.

${ }^{186} \mathrm{lbid}$. The judge ordered Wass sent to Newgate, where we lose trace of him

${ }^{187}$ Directions, p. 14.

${ }^{188}$ George Stacey \& Matthias Dennison, OBSP (Jan. 1741, \#\#24-25), 11, 12 (highway robbery).

189 Ibid. 13. The two defendants were convicted and sentenced to death. This case also evidences, ibid. 12-13, the earliest appearance in the Old Bailey Sessions Papers of Stephen Macdaniel (sometimes McDaniel), who would figure as the chief villain in 1754 in the great reward scandal discussed in Langbein, "Criminal Trial", pp. 110-14. Macdaniel appeared as a crown witness, testifying against his former accomplices. As as in his later exploits, this was a case of highway robbery, for which legislation offered a $\$ 40$ reward to those who prosecuted and convicted offenders. The reward system is discussed at pp. 356-360 below. Paley reports that in this case Parish, Macdaniel, and six others split $\mathrm{f} 80$ in reward money for convicting the two offenders. Ruth Paley, "Thief-takers in London in the Age of the McDaniel Gang, c. 1745-1754" [hereafter cited as Paley, "Thieftakers"], in Hay \& Snyder, pp. 301, 319. 
The Old Bailey trial sources also contain allegations about solicitors absconding, for example, the pitiful James English, accused in 1736 of stealing clothes, who was apparently believed and acquitted when he told the court: "I have not any Witnesses, for I gave all my Money to one Mac-something, a Newgate solicitor, to manage my Cause, and he is run away with the Money and has done nothing." 190

\section{B. The 1733 Grand Jury Presentment}

In September 1733, the London grand jury returned an extraordinary presentment, complaining that "many Vexatious and litigious Prosecutions have appeared before us. . .."191 The document points to two abuses. First, magistrates' clerks (who often practised as solicitors in their own right) were charging fees for the performance of the magistrates' public duties, hence confusing private employment and public office. ${ }^{192}$ Second, "Clerks and Solicitors in Confederacy with a set of People calling themselves informing Constables, Newgate Solicitors and others ... [were acting] as Solicitors and Agents ... [in] encouraging and Abetting ignorant and weak People to" bring insubstantial prosecutions, and consequently, "getting that Money from them which they stand in Need of for the Support of themselves and [their] poor families". ${ }^{193}$

The London grand jury's concern with vexatious prosecution needs to be understood in the light of a striking shortcoming of the early modern criminal justice system. Into the eighteenth century, the procedure lacked an effective pretrial screening mechanism to weed out insubstantial cases until the eve of trial, when the grand jury

19 James English, OBSP (Jul. 1736, \#13), 154.

191 CLRO, London Sessions Papers, September, 1733, document unnumbered [hereafter cited as 1733 Grand Jury Presentment]. The presentment was contemporaneously printed as a two-sided bill and is found bound with the September 1733 trial pamphlet in some collections of the Old Bailey Sessions Papers, for example, that of the University of Chicago Law Library, cited in Langbein, "Criminal Trial", p. 109 n. 441.

192 The Presentment says that "Divers Persons, Clerks or Servants to many of his Majesty's Justices of the Peace within this City, do under Color and in the Execution of their Office Exact and Take from all Persons accused and others bound to Prosecute Several Sums of Money under Pretence for Warrants, Commitments, Recognizances, Discharges and other Matters Incident to the Duty and Office of a Justice of Peace, contrary to the known Laws of this Realm, In Violation of public Justice and to the great oppression of his Majesty's Subjects." 1733 Grand Jury Presentment, note 191 above, at Ir.

A 1738 Old Bailey case illustrates the kind of thing the Grand Jury was complaining about five years earlier. In the prosecution of Joseph Golding, OBSP (Apr. 1738, \#22), 66, for highway robbery, a witness told of having gone to Justice Farmer's to give an information. Farmer's clerk, Warrener, refused to take it without being paid a Guinea. "The Court expressed their Resentment of Mr. Warrener's behaviour; and declared it to be the duty of all who serve as Clerks under Gentlemen in the Commission of the Peace, to be always ready to execute their Office without Exaction." Ibid. 67.

On the tension between the clerk's magisterial and private practice, see pp. 339-340 above.

193 1733 Grand Jury Presentment, note 191 above, at $1 \mathrm{r}$. 
reviewed all the proffered bills of indictment and could reject transparently preposterous ones. The rest of the cases went to trial. ${ }^{194}$ This "dependence on prosecutions initiated by private individuals", Ruth Paley has remarked, invited "vexatious actions". ${ }^{195}$ Indeed, the bare threat to institute a groundless prosecution was terrifying enough that it could be used to extort money. Thomas Neaves, a "Noted Street-Robber" active in the 1720s, boasted of his success at this technique. ${ }^{196}$ Behind the London grand jury's presentment is the discomfort that contemporaries felt that solicitors specialising in criminal prosecutions had at their fingertips the ability to subject citizens to the danger, expense, and humiliation of defending against criminal charges. ${ }^{197}$ The Old Bailey made an ineffectual regulatory response to the presentment, decreeing that the ranks of solicitors practising at the court would be restricted to persons "that have been

194 When confronted with an accusation of felony, the magistrate acting at pretrial "had only two options. . . He could jail the accused or bail him. He could not discharge him." Langbein, Prosecuting Crime, p. 7; see ibid. p. 124 n. 72, citing Dalton, (n. 14 above) p. 262, the authoritative justicing manual that articulates the point in the first edition in 1618 and carries it forward for decades in subsequent editions. Beattie traces the point into other earlyeighteenth-century practice manuals. Beattie, Crime, at p. 272 \& n. 13. By Blackstone's day the magistrates were able to dismiss if they found an accusation "wholly groundless." Beattie, Crime, pp. 280-281, citing William Blackstone, Commentaries on the Laws of England (1769) vol. 4, p. 293.

195 Paley, "Thieftakers", p. 312. Paley has traced the activities of several gangs of London thieftakers active in the $1740 \mathrm{~s}$ and $1750 \mathrm{~s}$, showing that they took advantage of the ease of charging to institute malicious prosecutions. $l$ bid. pp. 312-313 and n. 39 .

${ }^{196}$ He would "step to a Justice of the Peace, and having given some formal Account of a Robbery, sometime or other committed, he generally procured a Warrant, which he carried along with him, till he had an Opportunity of securing .. [his victims, unless they paid him off. Otherwise,] they were certainly charged in Custody, and sent to Prison on suspicion till he could (as he often pretended) find an Adversary to prosecute them." Anon., The Life of Tho/mas] Neaves, the Noted Street-Robber (London, n.d., c. 1729) p. 26, discussed in Langbein, "Criminal Trial", pp. 109-110,

Trumped up cases of sodomy were feared for their reputational damage. E.g., Anon., A Full and Genuine Narrative of the Conspiracy Carried on by Cather, Cane, Alexander, Nixon, Paterson, Falconer, Simith, Which Last Was Executed at Tybourn with McLeane, against the Hon. Edward Walpole, Esq.. Charging Him with the Detestable Crime of Sodomy, in Order to Extort a Large Sum of Money from Him. Together with an Account of Their Remarkable Trial and Conviction before the Rt. Hon. the Lord Chief.Justice Lee, in the Court of King's Bench, Westminster, July 5th. 1751. (London, 2nd ed. [1751]) (Beinecke Library, Yale Univ., shelfmark British Tracts 1751 F 95). Two such cases that came before Lord Mansfield in the $1770 \mathrm{~s}-R$. v. Foote (1776) (unreported), and R. v. Donnally, I Leach 193, 188 Eng. Rep. 199 (1779)-are discussed in James Oldham, "Truth-Telling in the Eighteenth-Century English Courtroom" (1994) I2 Law \& History Rev. 95, 107-108. Mansfield brooded in Donnally that such cases were "a specious mode of robbery of late grown very common. ..." Oldham, p. 108, citing Oldham, Mansfield Manuscripts, vol. 2, p. 929.

Evidence of a solicitor's involvement in a trumped up sodomy case appears in the Old Bailey prosecution of George Sealey \& Thomas Freeman, OBSP (Sept. 1736, \#\#78-79), 188. Freeman testified that the prosecutor "got acquainted with one Cuttings, a Solicitor in the Old Bailey, and they 2 gave . . Directions to draw the Bill for Sodomy against me." Ibid. 190.

197 The September 1733 Gentleman's Magazine reported that, in addition to the presentment discussed in text, "the Grand Jury presented 4 noted Solicitors for infamous Practices, in fomenting and carrying on Prosecutions against innocent Persons for the sake of Rewards, \&c, whereupon the Court returned Thanks to the Grand Jury and assured them that the Offenders should be rigorously prosecuted." 3 Gentleman's Magazine 493 (Sept. 1733). In a forthcoming book, John Beattie traces this report in the London records and identifies the four solicitors. Beattie, Urban Crime, chapter 9. 
admitted Sworn Attorneys in some of the Courts at Westminster and are amenable to Justice for Such their Practice". ${ }^{198}$

The image of the prosecuting solicitor as a figure of menace endured across the decades. It surfaced again, for example, in 1773 in Robert Holloway's vituperative tract, The Rat-Trap, ${ }^{199}$ which caricatures the London magistrate's clerk as a "petty-fogging attorney: a rascal so branded with infamous practices, that he is rendered too despicable for any employment but solicitor to a rotation office. This miscreant [has the power to] convict, or acquit, just as the prosecutor will pay, or the thief bribe. . . "200 Holloway purports to describe "a certain Old Bailey solicitor, who ... [after being dismissed] from the Bow-street Office [where Henry and then John Fielding served as the court J.P.], has met with such singular success in Litchfield-street [another magistrate's office], that he shares five hundred pounds per annum from indictments; and that from hanging and transporting innocent men at the price of five guineas each" ${ }^{201}$ Holloway concludes with a flourish that "an Italian assassin would demand double the wages for stabbing single-handed, that our bravo [solicitor] requires for a volume of sheer perjury". ${ }^{202}$

Contemporary concern about the ability of the solicitor to affect the reliability of the evidence was not confined to the prosecution. There was considerable fear of the Newgate solicitor's ability to concoct false alibis for defendants. An alarming example occurred in the prosecution of Thomas Gray, alias MacCray, ${ }^{203}$ for highway robbery in $1735 .{ }^{204}$ MacCray had been arrested near the scene of the robbery. The prosecuting victim, a clergyman, testified that he was quite certain of the identification. The moonlight at the scene of the holdup had been good, and the clergyman had seen the culprit full face. When arrested, MacCray had in his possession a lock and key that the prosecutor identified as part of the stolen loot.

Against this powerful case, the accused mounted a defence of alibi. Prosecuting counsel, mistrustful of the defence witnesses, asked to have them excluded from the courtroom during each other's

1981733 Grand Jury Presentment, note 191 above, at $1 v$. This response echoes the 1729 legislation for requiring the enrolment of solicitors, above at note 34 .

199 Robert Holloway, The Rat-Trap, Dedicated to the Right Hon. Lord Mansfield, Chief Justice of England: Addressed to Sir John Fielding, Knight (London 1773) (Lincoln's Inn shelfmark Law Pamphlets 29, no. 5).

${ }^{200}$ Ibid. pp. 15-16n. He continues: because "there is a good understanding kept up between the amiable trio, justice, solicitor, and thief-catcher, it is almost impossible to determine in many cases which ought to receive the reputation of hanging the innocent or screening the guilty." Ibid. p. $16 \mathrm{n}$.

201 Ibid.

${ }^{202}$ Ibid.

${ }^{203}$ MacCray was the leader of a gang of London criminals who figured in a number of Old Bailey cases in the period around 1735, and who are being studied in current research by Heather Shore.

204 OBSP (Jul. 1735, \#22), 89. 
testimony, explaining that "We fear some bad Practices. . . ."205 MacCray contended that the prosecution was a frame-up growing out of election hostilities, and that he had alibi witnesses placing him at a pub in Holborn on election business at the time of the robbery. His first witness, Gilbert Campbell, identified himself as an attorney, and testified that he took MacCray with him to the pub on a client's business. Two further witnesses corroborated Campbell's story, one Ruffhead, a butcher, and Julian Brown. Brown's appearance stirred Sir Thomas DeVeil, the court J.P., who was sitting with the trial bench, to recollect that Brown had been prosecuted for a robbery four years earlier, and had been lucky to be acquitted because the evidence against him was very full. Nevertheless, confronted with three unrebutted alibi witnesses, the jury acquitted MacCray.

The contemporaneous Old Bailey Sessions Paper account of MacCray's case underscores the reporter's distrust of the alibi witnesses. A footnote identifies Campbell as having been a defence witness in another felony case a few months before. ${ }^{206}$ Another footnote cites readers to the 1731 report of the prosecution of Brown. ${ }^{207} \mathrm{~A}$ posthumous biography of DeVeil, published in 1748, claims that a notorious solicitor, William Wreathock, masterminded the false alibis that saved MacCray. ${ }^{208}$ Wreathock was renowned as the attorney with the effrontery to bring the so-called Highwayman's Case in the Exchequer in 1725. That suit asserted a dispute about the profits of a joint venture. When the court discovered that both parties were highway robbers contesting their shares in stolen loot, the case was dismissed and Wreathock fined $£ 50$ for contempt of court. ${ }^{209}$ In 1735 Wreathock was convicted at the Old Bailey of highway robbery ${ }^{210}$ and sentenced to death but transported and ultimately pardoned. He returned to London, resumed practising as a solicitor, and was finally struck off the solicitors' rolls in $1758 .{ }^{211}$

The pamphlet biography of DeVeil also contends that the

${ }^{205}$ Ibid. 90.

206 Ibid.

207 Ibid. 91, citing Julian Brown, OBSP (Sept. 1731, \#7), 11. Months after he testified as a witness for MacCray, Brown was prosecuted and acquitted of the rape of an eleven-year-old girl. Julian Brown, OBSP (Oct. 1735, \#35), 161.

${ }_{208}$ Wreathock "had managed the whole scene of perjury, by which MacCray came off in Middlesex, and a very bold attempt of the same nature, by which it was endeavoured to get him acquitted likewise in Surrey, though that miscarried". Anon., Memoirs of the Life and Times of Sir Thomas DeVeil, Knight (London 1748) p. 38 [hereafter cited as DeVeil, Memoirs]. I owe the reference to this passage to Heather Shore, who is currently researching certain of the London criminal gangs active in the mid-1730s, including the MacCray-Wreathock group. Regarding DeVeil and this pamphlet biography, see Langbein, "Criminal Trial", pp. 59-60.

${ }_{209}$ The case, which arose on a bill in the equity side of the court of Exchequer, is unreported. The archive sources are discussed and extracted in Note, "The Highwayman's Case (Everet v. Willams)" (1893) 9 Law Q. Rev. 197-199.

210 William Wreathock et al., OBSP (Dec. 1735, \#\#67-71), 18.

211 Birks, (n. 33 above), pp. 135, 149; Holdsworth, $H E L$, vol. 12 p. 59. 
MacCray gang, alarmed at DeVeil's investigations of their "remarkable villainies", had planned in October of 1735 to have Julian Brown assassinate him, but that Brown became frightened and warned DeVeil. Among the MacCray gang, the pamphlet says, "were retainers to the law, who understood all the dark arts that qualified Newgate solicitors, and these fellows provided and managed every thing, and that too with such dexterity, that there was nothing they could not prove, or disprove upon very short notice". ${ }^{212}$ (This concern that London criminal gangs could call upon the skills of solicitors also troubled the reward system, discussed below.) MacCray himself appears to have been a sometime solicitor. MacCray appeared as the prosecuting victim in one of the earliest known cases in which defence counsel appeared at the Old Bailey, in December 1734. Crossexamined about his business, MacCray replied, "I practise the Law-_tis what I was bred to." 213

So ill was the repute of solicitors at the Old Bailey in these years that the anonymous author of a measured tract $^{214}$ about the case of Thomas Carr, a solicitor who was convicted and executed in 1737, argued that prejudice against solicitors had influenced the jury to return the mistaken capital verdict. Carr was convicted of committing a robbery at knifepoint and executed. The author, after discussing the evidence that pointed to Carr's innocence, speculated that the jury's error resulted in part from hostility to solicitors. "A common Prejudice against Mr. Carr's profession, especially in the Way he was sometimes unhappily engaged in [together with] A particular personal Prejudice against him, on his general Character of leading an irregular Life, and upon the Report of his having been concerned in the defence of certain Persons and Causes not altogether to his Credit, added to the seeming Consistence [sic] of the Prosecutor's well seamed Story, might sway, and prepossess their minds against him." 215

As of the mid-1730s, therefore, events had made the public and the bench increasingly aware of the danger that some solicitors in criminal practice would employ unscrupulous means to "prove . . .

${ }^{212}$ DeVeil, Memoirs, pp. 34-35.

${ }^{213}$ Margaret \& Hester Hobbs, OBSP (Dec. 1734, \#29), 16 (privately stealing from the person). The prosecution was brought by Thomas Gray, identified by the alias MacCreagh, that is, MacCray. He claimed the two women stole some money from him. Their defense was that the case was a grudge prosecution, deliberately orchestrated by the gang. The jury acquitted.

214 Anon, Some Observations on the Trial of Mr. Thomas Carr, Who Was Executed at Tyburn, January 18.1737 (London 1737) (Lincoln's Inn shelfmark Trials 101, no. 1.).

215 Ibid. p. 6. The case is reported as Thomas Car [sic] \& Elizabeth Adams, OBSP (Oct. 1737, \#\#4-5), 204. The jurors seem also to have been irritated at defence counsel's aggressive questioning of a prosecution witness. They are said to have requested that the trial judge "would please to ask the Questions that are proper, and that the [witness] may not be interrupted." lbid. p. 206. 
or disprove"216 whatever the case needed for victory. The judges' decision, taken in these years, to allow defence counsel to crossexamine witnesses at trial was, in my view, motivated in considerable part by their growing realisation of the potential for distortion and fabrication that inhered in the increasingly lawyerised pretrial that lay behind the trials over which they presided.

\section{Discrediting the Reward System IN THE 1730s}

In the same years that uneasiness was growing about the capability of solicitors to compromise the integrity of the evidence in criminal trials, the reliability of another pillar of early eighteenth-century prosecutorial practice-the reward system-was also shaken by scandal.

The essentials of the reward system are well described in the scholarly literature ${ }^{217}$ and can be treated here in summary. Beginning in 1692, Parliament enacted a series of statutes that offered $£ 40$ rewards to persons who would apprehend and convict offenders who had committed certain serious property crimes. ${ }^{218}$ The 1692 Act applied to highway robbery. In the next decades further legislation extended such offers to burglary and housebreaking, coining, theft of certain livestock, and other offences. ${ }^{219}$ The trial judges became intimately familiar with the administration of the reward system, because the statutes put them in charge of apportioning each reward among all the persons who claimed to have participated in procuring the conviction. ${ }^{220}$ In addition to the statutory rewards, the government episodically offered rewards by proclamation, often tailored to highway robbery or murder in the metropolis. ${ }^{221}$ When a statutory reward overlapped a proclamation, prosecuting highway robbers could be worth $£ 140$ a head, ${ }^{222}$ a stupendous sum at a time when a

${ }^{216}$ DeVeil, Memoirs, p. 35.

217 Beattie, Crime, pp. 50-59; Paley, "Thieftakers" (n. 189 above); Radzinowicz, History, vol. 2 pp. 57-137, 326-346; Langbein, "Criminal Trial", pp. 106-114.

2184 \& 5 Will. \& Mar., c. 8, \$2 (1692). Some of the statutes offered, in addition to or in place of cash rewards, so-called 'Tyburn tickets', negotiable certificates of immunity from parish and ward offices that traded freely in the aftermarket. See Radzinowicz, History, vol. 2, pp. 155-161.

${ }^{219}$ Compiled in Patrick Colquhoun, $A$ Treatise on the Police of the Metropolis (7th ed. London 1806), pp. 390-392 (1st ed. London 1795). Modern accounts appear in Beattie, Crime, pp. 50-59; Radzinowicz, History, vol. 2, pp. 57-60; Langbein, "Criminal Trial", pp. 106-114.

${ }^{220}$ Paley, "Thieftakers", pp. 317-318; Langbein, "Criminal Trial", pp. 107-108.

221 Beattie, Crime, pp. 52-53. Radzinowicz traced these proclamations well back into the seventeenth century and concluded that they inspired the later statutory system. Radzinowicz, History, vol. 2 , pp. 84-88.

${ }^{222}$ Paley, "Thieftakers", p. 324. The sense that $\mathrm{fl} 40$ was the going rate in London rather than the basic statutory reward of $£ 40$ appears in the statement at trial of one of the defendants, William Booth, in a highway robbery case prosecuted in 1733. Denouncing the accomplice witness appearing against him, Booth says, "I set down a Candle by him at the King's Arms, and it happened to burn his Wig, upon which he swore that Job should fetch him 1140 ." John Ackers et al., OBSP (Jan. 1733, \#\#34-36), 44, 45. Beattie believes that royal proclamations offering the supplementary $£ 100$ for offences committed within five miles of London were continuously in 
craftsman earned about $£ 20$ per year and a labourer less than $£ 15 .{ }^{223}$ Local authorities sometimes offered further rewards, as did private persons and the associations for the prosecution of felons. ${ }^{224}$

The reward system was designed to enhance the incentives to prosecute in a largely privatised criminal justice system, which lacked both police and public prosecutors in the modern sense. The danger that inhered in the reward system was that the thieftakers who responded to the reward incentives had no particular interest in distinguishing between the innocent and the guilty, hence that they would falsify evidence for the sake of the reward. In hindsight it is known that such incidents occurred repeatedly ${ }^{225}$ until the reward system was abolished in the nineteenth century. ${ }^{226}$ As early as 1696, only months after the enactment of the statute offering rewards for convicting counterfeiters and coiners, Sir Isaac Newton, the Warden of the Mint, wrote to the Treasury that "the new reward of forty pounds per head has now made Courts of Justice and Juries so averse from believing witnesses and Sheriffs so inclinable to impannel bad Juries that my Agents and Witnesses are discouraged and tired out by the want of success and by the reproach of prosecuting and swearing for money".227

Prosecuting for bounty, even prosecuting real offenders, was not a very attractive line of work, and it did not call forth genteel types. In her study of the thieftakers active in London in the decade from the mid-1740s, Ruth Paley found that "all had strong ties to the capital's criminal communities. Almost all had some kind of criminal record". ${ }^{228}$ Many were linked to criminal gangs, which engaged in extortion and blackmail as well as prosecutions for reward. Paley exaggerates, but not by much, when she contends that "the major effect of the provision of $£ 40$ rewards was to provide an incentive not to the detection of crime but to the organisation of thief-making conspiracies. ... [T]hief-takers were in business not to detect crime but to commit it". ${ }^{229}$

\footnotetext{
force for highway robbery and burglary in London from 1720 until 1744, and frequently thereafter until 1750. Beattie, Urban Crime, Ch. 9 (forthcoming).

${ }^{223}$ E.H. Phelps Brown \& Sheila V. Hopkins, "Seven Centuries of Building Wages", in E.M. CarusWilson, (ed.) Essays in Economic History (1962), vol. 2, pp. 168, 177 (table 1).

224 See Radzinowicz, History, vol. 2 pp. 98-137. On the activity of the associations in advertising rewards, see Styles, "Advertising" (n. 168 above), pp. 60-62. Owners of stolen goods also advertised rewards for the return of the goods and the apprehension and conviction of the culprits. The so-called Jonathan Wild Act, 3 Geo. I, c. 11 (1717) threatened heavy fines for offering no-questions-asked payments for the return of stolen goods.

${ }^{225}$ See the tabulation in Radzinowicz, History, vol. 2, p. 339 (instances in the years 1738-54); for nineteenth-century cases, see $i$ ibid. pp. 340-341.

${ }_{226}$ Bennet's Act, 58 Geo. III, c. 70, §1 (1818), discussed in Radzinowicz, History, vol. 2, pp. 74-82; see also Beattie, Crime, pp. $58-59$.

${ }_{227}$ Letter to the Commissioners of the Treasury, note 57 above, at p. 209.

${ }^{228}$ Paley, "Thieftakers", p. 304.

229 lbid. p. 323.
} 
The first of the great reward scandals broke in 1732. One John Waller was convicted at the Old Bailey of a misdemeanour in attempting to prosecute a person falsely for a highway robbery in order to collect the reward. Evidence was adduced that Waller had succeeded in bringing such prosecutions in other counties. He was convicted and sentenced to be pilloried. ${ }^{230}$ When he was exposed in the pillory at a location called the Seven Dials, the brother of one of his victims set upon him and beat him to death. The brother was subsequently tried at the Old Bailey, convicted of Waller's murder, and sentenced to death. ${ }^{231}$ The Waller case caused a sensation. The title of a contemporary pamphlet account suggests the horror that the saga evoked: The Life \& Action of John Waller, Who Made his Exit at the 7 Dials on 13 May 1732; Containing All the Villainies... Swearing Robberies Against Innocent People, to Take Away their Lives for the Sake of the Rewards. ${ }^{232}$

Waller was an individual entrepreneur at the business of false prosecution, not connected to a gang, and his tactics were primitive compared to the frame-ups staged by gangs in later decades. He would pretend to have been robbed outside a pub, where he identified some hapless person as the supposed attacker. ${ }^{233}$ At the trial it was Waller's word against the innocent accused. Groups such as the MacDaniel gang perfected better techniques for false witnessing in reward prosecutions. They employed several persons to give seemingly corroborating evidence-apprehenders of the accused robber, sometimes a feigned victim for the staged crime, and sometimes other supposed witnesses. ${ }^{234}$ The gangs were also cunning in their selection of victims. "Those entrapped were invariably young and inexperienced and were often newcomers to the capital ... [d]enied counsel and faced with what was in effect a professional prosecution conducted without regard to truth. . .."235

The Waller episode made the danger of false witnessing in rewarddriven prosecutions a subject of acute concern. Roughly from this time onward, we find some evidence in the skimpy trial narratives from the Old Bailey that defendants were beginning to claim that they were the victims of reward-driven frame-ups. This new line of defence suggests that defendants had detected from whatever sources a new sensitivity on the part of the courts to the danger of rewardtinged prosecutions. Mary Haycock, prosecuted by the Mint with her

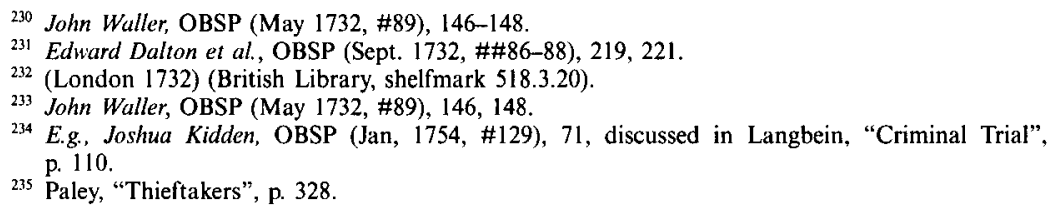


daughter Ann for coining in July 1734, was not believed when she insisted that the witnesses "only swear this against me for the sake of a Reward". ${ }^{236}$ John Busk, tried for burglary in February 1736, fared better. He told the court: "'Tis the Practice of these Thief-takers to take up young Fellows, make them drunk, and get them to say what they would have them, that they may take their Lives away for the sake of the Reward." ${ }^{237}$ The jury returned a partial verdict. ${ }^{238}$ It acquitted him of the burglary, rescuing him from capital punishment, hence denying the prosecutors any reward, but convicting him of the felony of theft above a shilling's value, for which he was sentenced to transportation.

Thus, just at the time when unease had grown about the reliability of solicitor-mounted prosecutions, grievous doubts were raised about the reliability of the evidence in prosecutions for rewardable offences such as robbery, burglary, coining, and the theft of horses and livestock. The judges' decision in the mid-1730s to admit defence counsel to probe prosecution evidence was motivated in part, in my view, by their sense of the hazard that had come to surround the reward system in these years. As with solicitor-directed cases, so with reward cases, there was a need to subject the proofs in such cases to greater scrutiny. Since no one inside the existing system was doing the job adequately, the decision was made to allow a new participant, defence counsel, to serve.

Once admitted, defence counsel did indeed probe reward prosecutions. The sources do not preserve much evidence of this work, although occasional mentions survive which permit us to see it from the 1740 s onward. ${ }^{239}$ By the mid-1780s, when for a few years ${ }^{240}$

\footnotetext{
${ }^{236}$ Mary \& Ann Haycock, OBSP (Jul. 1734, \#\#19-20), 149.

${ }^{237}$ OBSP (Feb. 1736, \#50), 78.

${ }_{238}$ lbid. Regarding the partial verdict system, see Langbein, "Criminal Trial", pp. 41-43, 52-55.

239 Following are a pair of examples from 1743-44:

Counsel for Patrick Kelly et al., OBSP (Feb. 1743, \#116-119), 70, prosecuted for coining, asked a witness, "Do you expect part of the Reward?" Ibid,, p. 72. The jury convicted but recommended mercy "[a]s the principal witnesses . . . were Persons of ill Characters. . . " Ibid. at 74. (The jury thus directed its doubts about the reliability of the evidence towards sanction rather than culpability. Juries were not instructed on the beyond-reasonable-doubt standard of proof until the end of the eighteenth century. See Langbein, "Privilege", pp. 1056-57.)

Counsel for Samuel Goodman, OBSP (Dec. 1744, \#69), 34, charged with highway robbery, cross-examined both the prosecutrix and her husband about prosecuting him "for the sake of the great reward. ..." lbid. pp. 35, 36. Both denied it. The jury convicted and Goodman was sentenced to death. (As an indicator of how primitive the law of evidence was at this time, notice that counsel is not reported voicing any objection when the husband testified that at the pretrial committal hearing the examining magistrate recognised the defendant and said to him, "Oh, my old Friend, where have you been all this while; what, ain't you hanged yet?" Ibid. p. 36.)

240 In the years $1783-1789$ the OBSP contain a number of particularly detailed trial reports. More cases were reported, and the volumes run considerably longer than before or later. These differences were associated with a change of reportership, to Edmund Hodgson. In 1790, however, with Hodgson still as reporter, there was a dramatic reduction in the number of pages per volume, achieved in part by publishing only trials that resulted in convictions. This policy was abandoned in 1793, when Hodgson was replaced as reporter.
} 
the Old Bailey Sessions Papers were especially revealing about the courtroom activities of counsel, we see the legendary defender William Garrow ${ }^{241}$ resolutely challenging the motives of rewardseekers and probing the circumstances of reward-based prosecutions. ${ }^{242}$ By the end of the century, Colquhoun wrote that defence counsel had become so successful in contesting reward-based prosecutions that "many notorious offenders often escape justice". ${ }^{243}$ Thus, across the eighteenth century, the dangers of the reward system became a vital raison d'etre for the work of defence counsel.

\section{CONClusion: Understanding a Silent Revolution}

In the mid-1730s the bench took the epochal decision to permit felony defendants to have the assistance of counsel for the limited purpose of examining and cross-examining witnesses. Unlike the Treason Act of $1696,{ }^{244}$ which allowed treason defendants to be represented by counsel, the decision in the 1730s did not take the form of legislation. Accordingly, it did not leave the characteristic traces that help us to understand the origins of an enactment. We have no statutory text, no preamble, no Journals of the two Houses, no papers of the parliamentarians. The change occurred in judicial practice, but because the change did not arise from adjudication, the judges did not leave decisional law to explain their thinking. This change in judicial practice is so poorly evidenced for its early decades that we are able to document it only through the study of obscure pamphlet trial reports that were all but unknown to legal historians until the 1970s. Lacking, therefore, any authoritative account of the rationale for the judges' decision, we are left to try to infer the judges' purposes from the surrounding circumstances.

In deciding to allow defence counsel in the $1730 \mathrm{~s}$, the judges surely took comfort from the precedent established by the Treason Act of 1696. Hawkins, it will be recalled, intimated in 1721 that a main reason that the Act's grant of defence counsel was limited to treason defendants was because treason cases were those in which

${ }^{241}$ On whom, see Beattie, "Scales", at pp. 236-247.

${ }^{242}$ E.g., James Wingrove, OBSP (May 1784, \#637), 818, 821 (acquittal); William Horton, OBSP (Jul. 1784, \#735), 970, 971 (acquittal); Robert Mitchell, OBSP (Dec. 1784, \#190), 196, 197 (acquittal; Garrow cross-examined the prosecutor about the number of times he had previously prosecuted robberies supposedly done to his person); John M'Carty \& Thomas Hartman, OBSP (Dec. 1787, \#28), 45-47 (convicted of simple theft and transported); William Eversall et al., OBSP (May 1788, \#333), 436, 437 (acquittal); John Wood, et al., OBSP (May 1788, \#374), 477 (convicted; jury recommended mercy); Thomas Gibbs, OBSP (Dec. 1788, \#44), 28-29 (acquittal); Thomas Jones, OBSP (Dec. 1788, \#76), 48, 49 (acquittal).

${ }^{243}$ Patrick Colquhoun, note 219 above, at p. 222 (London, 1796 ed.), cited by Beattie, Crime, p. 374.

2447 \& 8 Will. 3 , ch. 3 (1696), discussed at p. 317 above. 
lawyers appeared for the crown. Treason prosecutions, he wrote, "are generally managed for the Crown with greater Skill and Zeal than ordinary Prosecutions. . . ."245 By the 1730s, the lawyer's hand was increasingly apparent in "ordinary Prosecutions". The Treason Act meant to even up for the advantages of the insistently lawyerised treason prosecution. When in the 1730s the judges began allowing defendants to have the help of counsel to probe the sometimes menacing evidentiary product of prosecutions that were increasingly solicitor-driven and reward-tainted, they were effectively pursuing a similar rationale of evening up.

There is some risk that it is misleading to speak of "a decision" to admit defence counsel in the 1730s. Initially, the change may have taken place episodically in the work of individual judges, exercising their traditional discretion to conduct their trial calendars. The first departures may have occurred as mere exceptions, without intent to abrogate the rule. The case of Edward Arnold in 1724, discussed above in another connection, ${ }^{246}$ shows the potential for the exercise of such discretion. There, it will be recalled, the trial judge allowed a solicitor to perform counsel-like functions, defending a deranged accused. ${ }^{247}$

The sense that defence counsel's right of audience lay within the discretion of the trial judge is an idea that long persisted. In December 1738, a few years after the change in Old Bailey practice, one Old Bailey judge was recorded resisting it. When a felony defendant told the court that "I have feed counsel", (that is, engaged counsel by paying his fee), the judge, echoing Hawkins' rationale for excluding defence counsel, responded: "But here is no Point of Law; and you know Matters of Fact as well as your Counsel."248

Doubt about the reach of the new rule allowing defence counsel to examine and cross-examine was voiced by prosecution counsel in the 1741 trial of Samuel Goodere for murder at Bristol, a case reported verbatim in the State Trials. ${ }^{249}$ When the trial judge ${ }^{250}$ asked the accused whether he wished to cross-examine a main witness, his counsel intervened to ask the court to "indulge counsel to put his

${ }^{245}$ Hawkins, vol, 2, 402.

${ }^{246}$ Edward Arnold, 16 St. Tr. 695 (Surrey Assizes, 1724), discussed at p. 330 above.

24716 St. Tr. 758.

248 Robert Andrews, OBSP (Dec. 1738, \#16), 9, 11.

$24917 \mathrm{St}$. Tr. 1003 (1741), discussed in another aspect, note 76 above. 1 directed attention to the passage extracted below, in text at note 252, in Langbein, "Lawyers", pp. 313-314.

250 Michael Foster, then sitting as Recorder of Bristol, later (1746-1763) a King's Bench judge and author of the work commonly known as Foster's Crown Law, which was the first important book on English criminal law written after Hawkins. Michael Foster, A Report of Some Proceedings on the Commission of Oyer and Terminer and Gaol Delivery for the Trial of the Rebels in the Year 1746 in the County of Surrle Jy, and Other Crown Cases; To Which Are Added Discourses upon a Few Branches of the Crown Law (Oxford 1762). 
questions for him. ..."251 Prosecution counsel still thought it worth his while to object, emphasising in this striking passage his understanding of the extent of judicial discretion about whether and how to allow defence counsel to cross-examine:

This, I apprehend, is a matter purely in the discretion of the Court, and what can neither in this or any other court of criminal justice be demanded as a right. The judges, I apprehend, act as they see fit on these occasions, and few of them (as far as I have observed) walk by one and the same rule in this particular: some have gone so far, as to give leave for counsel to examine and cross-examine witnesses; others have bid the counsel propose their questions to the Court; and others again have directed that the prisoner should put his own questions: the method of practice in this point, is very variable and uncertain; but this we certainly know, that by the settled rule of law the prisoner is allowed no other counsel but the Court in matters of fact, and ought either to ask his own questions of the witnesses, or else propose them himself to the Court. ${ }^{252}$

This account, insisting that the new rule allowing defence counsel to examine and cross-examine witnesses was "purely in the discretion of the Court", and that "few of [the judges] . . . walk by one and the same rule", supports the view that the change did not arise from any authoritative decision or directive, but rather emerged from the judges' exercise of their residual discretion over trial management.

The discretionary character of the changed practice allowing defence counsel was long remembered. In an Old Bailey case heard in 1786 the defence counsel William Garrow objected when the presiding judge, Heath J., allowed a prosecution witness who was mute to be examined through an interpreter. According to a manuscript report of the exchange, Garrow persisted after the court overruled his objection. Heath then upbraided him, reminding him: "What you do here is by permission of the Court in a Criminal Case." 253 The courts also exercised a discretion to relieve against the restriction of the new rule that limited counsel to examining and cross-examining, hence to permit what came to be called "full defence of counsel". In an Old Bailey case in 1771, William Davis, charged with robbing the mails, was unwell when tried. "The judge said, that as the prisoner was ill he would permit his counsel to state his defence to the jury." 254

As the submission from prosecution counsel in 1741 in Goodere

25117 St. Tr. 1022.

252 lbid.

${ }^{253}$ Manuscript bound with the Harvard Law Library's exemplar of the Old Bailey Sessions Papers for January 1756, following the case of William Bartlett, OBSP (Jan. 1756, \#151), 247. The quoted language appears at $\mathrm{lv}$, emphasis original.

254 William Davis, OBSP (Dec. 1771, \#40), 16, 25. 
indicates, the retreat from the rule against defence counsel appears to have been settled to some extent on a court-by-court basis. In an exceptionally well reported Old Bailey case from July 1742, defence counsel referred to his understanding that there was a "Course of the Court at the Old Bailey" regarding the scope of defence permitted to counsel, ${ }^{255}$ that is, a rule particular to that court. These variations further underscore that the abrogation of the old rule against defence counsel is not likely to have occurred in an authoritative pronouncement. (Small differences in the expected conduct of prosecution counsel also persisted among the assize circuits into the nineteenth century. ${ }^{256}$ )

Nevertheless, allowing for the hesitancy and the small inconsistencies, the judges in the mid-1730s certainly did change course away from the centuries-old ban on defence counsel in cases of felony. They have left us to infer their reasons. The theme of this article is that the judges were reacting to the sense of imbalance that had opened up between the prosecution and the defendant as a result of two major prosecutorial initiatives of the early eighteenth century, the increasing lawyerisation of the prosecution and the reward system, each having come by the mid-1730s to be understood to be deeply problematic.

The judges were also aware from the trials transpiring before them that a third great prosecutorial initiative was under way in this period. The London magistracy was aggressively developing the technique now known as the crown witness prosecution (in American parlance, allowing the accused to turn state's evidence). The magistrate offered immunity to an accomplice in return for his cooperation in testifying against other culprits. ${ }^{257}$ It came to be understood that the crown witness system harboured incentives to false witness perhaps as dangerous as those of the reward system. Just as a reward-seeking prosecutor had no intrinsic interest in whether his $£ 40$ bounty came from convicting the guilty or the innocent, neither did a crown witness who testified to save himself from the noose. By the 1740s the bench had responded to the dangers

${ }^{255}$ Counsel said that "he knew by the Course of the Court at the Old Bailey, he was not at Liberty to observe upon the Prosecutor's Evidence," but he was allowed to open (that is, introduce) the defence case "without making any Observations upon it." James Annesly \& Joseph Redding. OBSP (July 1742) (supplementary pamphlet), 19 (murder). The case also appears at $17 \mathrm{St}$. Tr. 1093, 1113 (Old Bailey 1742).

${ }^{256}$ Second Report from His Majesty's Commissioners on Criminal Law (1836) 10n (discussing circuit differences in the practice of previewing the prosecution evidence for the judge and jury in an opening statement).

${ }^{257}$ I have described the practice in the $1750 \mathrm{~s}$ in Langbein, "Criminal Trial", pp. 84-103. Writing about "Street Robberies" in 1751, Henry Fielding reported: "The Method of discovering these is generally by means of one of the Gang, who being taken up, perhaps for some other Offence, and, thinking himself in Danger of Punishment, chooses to make his Peace at the Expense of his Companions." Fielding, Enquiry, p. 158. 
of false witnessing in crown witness cases by fashioning the corroboration rule for accomplice testimony, ${ }^{258}$ one of the earliest of the exclusionary rules of evidence. Thereafter, the probing of crown witness cases became a central sphere of the activity of defence counsel at the Old Bailey. Although crown witness prosecutions began to loom large in the mid-1730s, ${ }^{259}$ the corroboration rule does not appear to be in place until the 1740s, hence after the introduction of defence counsel and quite possibly as a result of counsel's demonstration of the weaknesses of crown witness cases. ${ }^{260}$

The likely precipitating factor in the relaxation of the ban on defence counsel was the judges' recognition of the increasing unreliability of the evidence in the solicitor-driven and reward-driven prosecutions of the 1730s. The fundamental flaw in English criminal procedure, the failure to develop public policing and prosecutorial institutions appropriate to the dawn of the urban age, was beyond the mission of trial judges to rethink and to correct. Confronted with the deeply deficient evidentiary product of a partisan and privatised pretrial, the judges decided to allow defendants to invoke the aid of private lawyers for protection at trial. This decision to admit defence counsel to probe menacing evidence became in the light of hindsight a milestone on the road towards the adversary system of lawyerdominated trial.

The resort to defence counsel from the 1730s onward also perpetuated and helped entrench the principle that the trial court would shoulder no responsibility to investigate on its own. In the 1741 trial of William Warner and another for a nighttime highway robbery, ${ }^{261}$ we find a poignant reminder of the path not taken. Prosecution witnesses testified that they were certain of their identification of the two defendants, because the scene of the robbery was bright and starlit. The defendants protested that the night was dark and rainy. Warner pitifully suggested to the trial judge, "I hope you will look into it, and see whether it did [rain] or no". ${ }^{262}$ An

${ }^{258}$ The earliest unambiguous cases in the Old Bailey reports arise in the December 1744 sessions: James Leekey, William Robinson, \& Elizabeth Cane, OBSP (Dec. 1744, \#\#7-9), 5 (burglary; receiving stolen property); John \& Edward Hill, OBSP (Dec. 1744, \#\#26-27), 9 (highway robbery); James Ruggles et al., OBSP (Dec. 1744, \#\#93-95), 48, 49 (highway robbery).

${ }^{259}$ For example, in the February 1733 sessions there were four. Joseph Fretwell, OBSP (Feb. 1733, \#32) 61 (highway robbery); William West \& Andrew Curd, OBSP (Feb. 1733, \#\#38-39), 67-69 (burglary); Leonard Budley \& William Harris, OBSP (Feb. 1733, \#\#51-52), 69-71 (highway robbery); William Norman, OBSP (Feb. 1733, \#58), 71 (burglary).

260 The defendants in one of the three early corroboration-rule cases, John \& Edward Hill, OBSP (Dec. 1744, \#\#26-27), 9 (highway robbery), cited note 258 above, are shown as being represented by counsel in that sessions when tried on another indictment. John \& Edward Hill, OBSP (Dec. 1744, \#\#24-25), 8-9 (highway robbery).

Henry Fielding chafed at the corroboration rule, a recent innovation in his day that restrained his investigative and prosecutorial work as court J.P. for Middlesex. Fielding, Enquiry, pp. $158-163$.

${ }^{261}$ William Warner \& John Newman, OBSP (Dec. 1741, \#\#5-6), 3 (highway robbery).

${ }^{262}$ Ibid. p. 4. 
English trial court was powerless to respond to this sensible suggestion. In the English system of criminal procedure, a busy judge on loan from one of the central courts of civil jurisdiction at Westminster presided over a packed trial calendar at the Old Bailey or at an assize court for a few days. Unlike his Continental counterpart, the English judge had no prior familiarity with the evidence, and no investigative resources within the court. Thus, in William Warner's case, the court ignored his plea for further investigation and left it to the jurors to decide, without any additional evidence, between the two tales that had been presented to them. They chose the prosecutor's and hanged Warner. 